\title{
Neurological Disturbances of Ciguatera Poisoning: Clinical Features and Pathophysiological Basis
}

\author{
Killian L'Herondelle ${ }^{1}$, Matthieu Talagas ${ }^{1,2} \oplus$, Olivier Mignen ${ }^{3}$, Laurent Misery ${ }^{1,2}(\mathbb{D}$ \\ and Raphaele Le Garrec $1, * \mathbb{D}$ \\ 1 University of Brest, School of Medicine, Laboratoire Interactions Epithéliums-Neurones (Univ Brest, LIEN), \\ F-29200 Brest, France; killianlherondelle@gmail.com (K.L.); matthieu.talagas@chu-brest.fr (M.T.); \\ laurent.misery@chu-brest.fr (L.M.) \\ 2 Department of Dermatology, University Hospital of Brest, F-29200 Brest, France \\ 3 University of Brest, School of Medicine, INSERM U1227, Lymphocytes B et auto-immunité, \\ F-29200 Brest, France; olivier.mignen@univ-brest.fr \\ * Correspondence: rlegarrec@univ-brest.fr
}

Received: 31 August 2020; Accepted: 12 October 2020; Published: 14 October 2020

\begin{abstract}
Ciguatera fish poisoning (CFP), the most prevalent seafood poisoning worldwide, is caused by the consumption of tropical and subtropical fish contaminated with potent neurotoxins called ciguatoxins (CTXs). Ciguatera is a complex clinical syndrome in which peripheral neurological signs predominate in the acute phase of the intoxication but also persist or reoccur long afterward. Their recognition is of particular importance in establishing the diagnosis, which is clinically-based and can be a challenge for physicians unfamiliar with CFP. To date, no specific treatment exists. Physiopathologically, the primary targets of CTXs are well identified, as are the secondary events that may contribute to CFP symptomatology. This review describes the clinical features, focusing on the sensory disturbances, and then reports on the neuronal targets and effects of CTXs, as well as the neurophysiological and histological studies that have contributed to existing knowledge of CFP neuropathophysiology at the molecular, neurocellular and nerve levels.
\end{abstract}

Keywords: ciguatera; ciguatoxin; neurological; sensory; pathophysiology

\section{Ciguatera: An Underreported and Misdiagnosed Disease Lacking Effective Prevention and Treatment}

Ciguatera fish poisoning (CFP) is the most prevalent seafood poisoning worldwide, affecting mainly tropical and subtropical countries but also increasingly more temperate regions. Whereas this disease has existed for centuries, three major challenges remain: its prevention, diagnosis and treatment are poorly managed. CFP is caused by the consumption of reef fish belonging to usually edible species but which have been contaminated with ciguatoxins (CTXs). These toxins originate from benthic microalgae of the genus Gambierdiscus and Fukuyoa [1-3], which naturally populate coral reefs. Under the influence of poorly understood factors, these microalgae can proliferate and produce precursors of the congeners that intoxicate humans. Among these microalgal CTXs, which are called gambiertoxins (GTXs), CTX-4A [4,5], CTX-4B [5,6] and CTX-3C (Figure 1) [7,8] have been isolated from Pacific strains of Gambierdiscus spp. and herbivorous fish species involved in CFP outbreaks. Toxin-producing microalgae ingested by herbivorous grazing fish (of, e.g., the Scaridae or Acanthuridae families, which are especially incriminated in French Polynesia) are in turn eaten by carnivorous fish (such as species from the families Muranidae, Serranidae, Lutjanidae and Carangidae) [9]. During this transfer, GTXs are not only accumulated within the marine food chain but also biotransformed to become more polar and more toxic CTXs [10]. In the Pacific Ocean, the ultimate product of 
these toxifying biotransformations is Pacific-ciguatoxin-1 (P-CTX-1, also known as CTX1B), which is the most toxic for mammals of all CTXs known to date. Isolated from carnivorous fish from the Pacific Ocean [11], it is approximately 10-fold more potent in mice [10] and 50-fold more potent on the membrane potential of frog myelinated nerve fibers [12] than its microalgal precursor CTX-4B. In addition to fish, marine invertebrates such as giant clams have also been recently incriminated in ciguatera poisoning [13,14]. In addition to GTXs, which are lipid-soluble and therefore readily absorbed and slowly eliminated in fish and humans, Gambierdiscus spp. produce water-soluble toxins, including maitotoxins, gambierol and gambieric acids. However, until now there has been no evidence for their involvement in human CFP cases [15].

The distribution of ciguateric areas is sporadic (temporally variable), sometimes highly localized, and so far, unpredictable. Prevention of CFP cases could be achieved by detecting ciguateric fishes prior to consumption. This remains a challenge because CTX levels in fish that can cause adverse health effects in consumers are as low as parts per billion $[16,17]$. Ciguateric fish are indistinguishable from uncontaminated ones with regard to taste, smell, and appearance. CTXs are thermo- and relatively acidand basic-stable toxins that are unaffected by cooking, salting or congealing [16]. Currently, there are no portable assays available to detect CTXs in fish in the field prior to consumption. To achieve this goal, the development of an enzyme-linked immunoassay (ELISA) is attractive for its accuracy, sensitivity, routine and portable use, and recent progress is promising [18-21]. Laboratory methods such as cell-based assays and HPLC-MS(/MS) are useful to detect, quantify and/or identify CTXs after suitable extraction from fish meal remnants $[8,17,22-27]$ and mammalian fluids or tissues following intoxication [28-30]. Chemical methods are also used in a few laboratories to purify CTXs. Only small amounts of pure CTXs are available worldwide as chemical standards to monitor CTXs in marine foodstuffs or to confirm a CFP diagnosis and to study the pathophysiology of CFP disturbances.

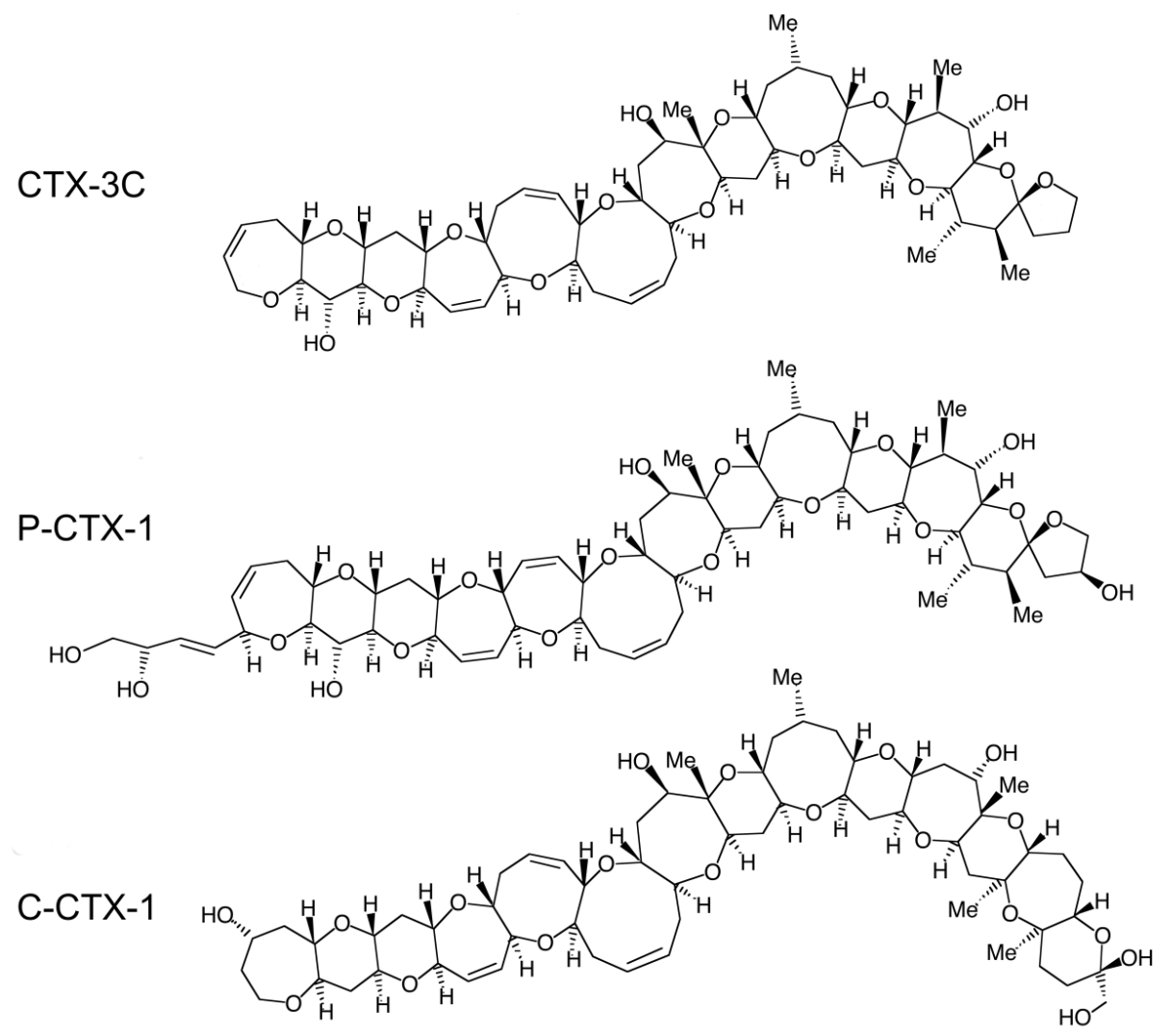

Figure 1. Structures of CTXs isolated from fish of the Pacific Ocean (CTX-3C and P-CTX-1) and the Caribbean Sea (C-CTX-1). The structure of the Indian-CTXs has not been characterized yet. From $[7,11,31]$, respectively. 
CFP is a common disease in the Asia-Pacific region [32-34], Caribbean area [35] and Indian Ocean islands [36]. Several groups of CTXs have been isolated from fish from these regions, namely, Pacific (P-CTXs, including P-CTX-1, Figure 1) [6,11], Caribbean (C-CTXs, including C-CTX-1, Figure 1) [31,37-39] and Indian (I-CTXs) [40,41] CTXs, respectively. The global incidence of CFP is estimated to be $50,000-500,000$ cases per year $[16,36,42,43]$, with the highest incidences reported in Pacific Islands [44-46] (see [15] for details). The large range of incidence estimates takes into account the large number of underreported cases in endemic regions of CFP and the misdiagnosed cases in nonendemic areas [47]. The incidence of ciguatera in nonendemic areas is increasing with the increase in fish imports and tourism [48-51], and global warming has tended to extend the areas concerned [52-55]. CFP diagnosis in human cases is usually based on clinical signs, which are well known in endemic areas. The variety of CFP symptoms, and in some cases, their persistence (see Section 2) constitutes a challenge in its diagnosis for clinicians and suffering for patients. In nonendemic regions, misdiagnosis is frequent because CFP symptomatology is poorly recognized, especially the relapsing symptoms that can reoccur months after the ciguateric meal, thus making the link difficult to establish. CFP treatment is only symptomatic, with limited efficacy, especially for the most distressing sensory symptoms (see Section 4). This review first aims to describe the CFP clinical features, on which diagnosis is largely based, focusing on neurological symptoms, especially sensory disorders. The second part reports the neuronal targets and effects of CTXs, and the neurophysiological and histological studies that have contributed to the knowledge related to CFP neuropathophysiology at the molecular, neurocellular and nerve levels, which could be the basis for the development of specific treatments.

\section{Clinical Features of Ciguatera}

Clinically, CFP is a polymorphous syndrome. Furthermore, in some cases, the time course of its symptomatology is unusual. Indeed, in addition to disturbances that immediately follow the ingestion of the toxic fish, it is not rare that some symptoms reoccur months or even years after exposure.

\subsection{Clinical Features of Acute CFP: A Variety of Neurological Signs with Pathognomonic Sensory Disturbances}

The acute phase of CFP symptomatology includes a wide spectrum of symptoms, which have been well documented, especially in the Pacific, and to a lesser extent, in Caribbean regions. They comprise digestive, neurological, cardiac and general troubles that can occur in multiple combinations. Among this variety of symptoms, neurological and especially sensory disorders (abnormal sensations) predominate in all cases.

The first symptoms appear a few minutes to $24 \mathrm{~h}$ after the toxic fish meal, but occur between 1 and $6 \mathrm{~h}$ in $90 \%$ of cases [56]. Onset symptoms are typically circumoral and distal paresthesia (see details below) and/or a digestive syndrome, both of which develop early. Gastrointestinal disorders include nausea, vomiting, abdominal pain and diarrhea (watery stools). Neurological symptoms begin with early paresthesia on the face and especially around the mouth (lips, tongue), then rather involve the extremities. Pruritus (itch), which is a very common symptom, begins 1 to 2 days after the ciguateric meal, sometimes associated with a skin rash. Painful sensations on contact with cold (cold dysesthesia) appear mostly within the first 2 days. Myalgia, especially in the muscles of the legs, is also frequently reported, as well as other sensory disorders, including a metallic taste, feeling cold (which is associated with hypothermia), superficial hyperesthesia with sensations of burning and electric discharges, arthralgia mainly affecting the large joints (knees, ankles, shoulders and elbows), dental pain, headaches, painful micturition and other urogenital pain. Autonomic signs, including profuse sweating or hypersalivation, are also often described. Motor disorders, including muscle weakness and general asthenia, are common complaints [32,35,36,44,57-61]. 
Among the sensory disturbances, in most cases, three particular signs are characteristic: paresthesia, cold dysesthesia and pruritus. Associated with the knowledge of a fish meal followed by a digestive syndrome, these sensory disturbances allow for the diagnosis of ciguatera poisoning, i.e., are pathognomonic symptoms of CFP.

\subsubsection{Paresthesia}

The first signs to appear, if there are no preceding digestive disorders, are circumoral paresthesia described as an unpleasant tingling, prickling and/or numbness around the lips as well as the nose, tongue and throat [62-64]. Intense paresthesia also affects the limbs, especially the extremities but also the arms and legs. Acral paresthesia does not develop as early as perioral paresthesia but belongs to the signs that may persist for one to several weeks after the incriminated meal [65-67].

\subsubsection{Cold Dysesthesia}

With a high frequency regardless of the geographic area [68], and especially in the South Pacific (87\% of 12,980 cases reported in French Polynesia) [32,60], this is one of the pathognomonic signs of CFP. Cold dysesthesia is described as painful tingling, burning, smarting, "electric shock" or "dry ice" sensations in the skin when it comes into contact with normally innocuous cold (cool water or objects), especially on the palms of the hands or soles of the feet [63]. The oral mucous membranes are also affected by cool drinks $[44,69,70]$.

Although "paradoxical sensory disturbance" or "reversal of temperature perception" is frequently reported, gross temperature perception was found to be unaltered in a study devoted to this particular symptom [69]. Tingling and burning sensations to cold were triggered from 24 to $26^{\circ} \mathrm{C}$ in five CFP patients whereas they normally appear below $15^{\circ} \mathrm{C}$ and $4{ }^{\circ} \mathrm{C}$, respectively [71]. Cold temperatures were perceived as burning or hot but different from the sensation evoked by noxious hot, and above all intensely painful. Of note, intradermal P-CTX-1 injection in human subjects has been shown to cause cold allodynia at concentrations higher than those inducing itch [72].

A functional magnetic resonance imaging (fMRI) study showed that brain areas responding to cold following intracutaneous injection of P-CTX-1 in human volunteers were located in the medial insula, the medial cingulate cortex, the secondary somatosensory cortex, frontal areas and the cerebellum [73].

\subsubsection{Pruritus}

CFP is called "the itch" (la gratte) in the French-speaking South Pacific countries [32] but also "la gratelle" in the French West Indies [74], which reflects that itch is a common symptom. CFP pruritus is occasionally associated with a skin rash. It is first localized on the palms of the hands and the soles of the feet, which can be associated with peeling skin, and then it becomes generalized. Pruritus affects the limbs, the face or more diffuse areas, and is exacerbated at night $[44,57,63,75,76]$. Scratching lesions can become infected. CFP pruritus commonly persists or relapses for a long time, reoccurring especially after alcohol consumption or other factors that increase skin temperature or blood flow [77].

\subsection{Cardiovascular and central Neurological Disorders in the Most Severe Cases}

Cardiovascular disorders are not common and occur in only severe cases of CFP, in which the vital parameters need to be monitored. When present, cardiovascular disturbances occur within the first $24 \mathrm{~h}$ and usually consist of hypotension and bradycardia, or rarely tachycardia [78-80].

In severe CFP cases, in addition to peripheral neurological disturbances, symptoms reflecting abnormalities of the cranial nerves and cerebellar and central motor functions can occur. These include vertigo, visual and/or oculomotor disturbances, reduction or abolition of deep tendon reflexes, paresis and impaired motor coordination, with some cases developing an inability to stand or walk (ataxia). Ventilatory difficulties and distal cyanosis are present in the most severely affected individuals. Some cases of coma and death, although rare, have been described [32,49,57,81-85]. The CFP fatality 
rate has been estimated at $0.1-1 \%$. Death is often associated with the consumption of ciguateric fish viscera, especially the liver, which contains higher levels of CTXs than the flesh $[23,32,44,86]$.

\subsection{Persistent and Relapsing Symptoms for Weeks, Months or Years}

After acute exposure to CTX, digestive and cardiovascular disorders generally disappear within a few days, unlike the neurological and especially the sensory disorders. The persistence or relapse of these for weeks, months, and sometimes beyond, is undoubtedly one of the most distressing and disabling characteristics of CFP. These symptoms include pruritus, distal paresthesia, cold dysesthesia and arthralgia associated with fatigue $[32,87,88]$. The frequency of cases of so-called chronic ciguatera (i.e., chronic symptoms after acute exposure to CTX) has been estimated to be $5 \%-20 \%[88,89]$ but reached $34 \%$ in one study [90]. These symptoms persist intermittently without any particular triggering factor and/or reappear after the consumption of certain drinks or foods, especially alcohol but also peanuts, nonciguateric seafood, pork or poultry $[64,66,91]$. Occurring long after the incriminated meal, they make the diagnosis difficult, in particular for physicians unfamiliar with CFP.

In addition, unusual cases of chronic inflammatory conditions such as polymyositis and arthritis occurring months or years following CFP have been reported [92-94]. Whether these are related to CTX immune effects or immune parameter dysfunctions found in CFP patients remains to be clarified [95-97]. In addition, a few case reports or studies have documented repercussions on the mind and cognitive functions, including a tendency to develop depression, in CFP cases with chronic symptoms [98-100]. Such alterations have been observed in mice following repeated exposure to P-CTX-1 [101].

\subsection{Factors Underlying the Variability in Ciguatera Symptomatology}

Ciguatera symptomatology is polymorphous, and the nature and intensity of the symptoms described in case reports vary considerably. The factors behind this variability include the multiplicity of responsible toxins. The nature of the CTX congeners involved varies according to the fish trophic level (the transfer being associated with toxin bioactivation), age-related size (bioaccumulation) and species [61]. Some identified species are even popularly associated with a particular clinical sign, such as Seriola fasciata (lesser amberjack), which is known in the French West Indies to induce scalp pruritus and hair loss, and is thus called "the hairdresser" [35]. Slight structural differences between Caribbean, Indian and Pacific Ocean analogs of CTXs may explain subtly variable clinical signs from region to region. However, early digestive syndrome, acute and chronic peripheral neurologic disorders, and cardiovascular symptoms in severe cases are reported regardless of the geographic area $[35,68]$.

Symptom variability among individuals sharing a fish meal may be related to the toxin amount ingested, which depends on the portion size and the fish part ingested. Previous and especially repeated exposure increases the illness severity, symptom intensity and individual sensitivity [32].

\section{Pathophysiological Basis of Ciguatera Neurological Disturbances}

The primary molecular neuronal targets of CTXs were identified a long time ago and continue to be refined. Electrophysiological studies have been performed with a number of excitable cells, and several major effects of CTX have been documented at the neurocellular level (see Table 1). In addition, neurophysiological and histological studies complement the knowledge related to CFP neuropathophysiology. 
Table 1. Electrophysiological and neurocellular effects of CTXs.

\begin{tabular}{|c|c|c|}
\hline CTX Effect & Model & Reference \\
\hline \multirow{9}{*}{$\begin{array}{l}\mathrm{Na}_{\mathrm{v}} \text {-mediated depolarization } \pm \\
\text { spontaneous firing }\end{array}$} & Mouse differentiated neuroblastoma N1E 115 cells & [102] \\
\hline & Frog myelinated nerve fibers & {$[103,104]$} \\
\hline & Guinea pig atrial heart muscle cells & {$[105]$} \\
\hline & Frog motor nerve terminals of NMJs & [106] \\
\hline & Guinea pig sympathetic ganglia & [107] \\
\hline & Rat parasympathetic neurons & {$[108,109]$} \\
\hline & Rat skeletal myotubes & [110] \\
\hline & Rat and mouse DRG neurons/afferents & [111-113] \\
\hline & Mouse cortical neurons & [114] \\
\hline \multirow{9}{*}{ Swelling } & Ranvier nodes of frog myelinated nerve fibers & {$[104,115-117]$} \\
\hline & Rat DRG neurons & [118] \\
\hline & Frog motor nerve terminals & {$[115,119,120]$} \\
\hline & Human adaxonal Schwann cell cytoplasm & [59] \\
\hline & Human intra-epidermal and sural nerve fibers & {$[70,121]$} \\
\hline & Human corpus callosum & {$[122,123]$} \\
\hline & Mice myenteric plexus nerves & {$[124,125]$} \\
\hline & Mouse and frog erythrocytes & {$[124,126,127]$} \\
\hline & Endothelial lining cells of heart capillaries & [128] \\
\hline \multirow{14}{*}{ Neuromediator release } & ACh release from (parasympathetic innervation of): & \\
\hline & Cat cardiovascular system & [129] \\
\hline & Guinea pig and mouse small intestine, taenia caeci and ileum & {$[125,130-132]$} \\
\hline & Frog atrial muscle & [133] \\
\hline & Frog motor nerve terminals of skeletal NMJs & {$[106,120]$} \\
\hline & Torpedo cholinergic synaptosomes & [134] \\
\hline & NAd release from sympathetic innervation of: & \\
\hline & Guinea pig and human atria & {$[105,132,135-137]$} \\
\hline & Guinea pig vas deferens & {$[130,131,138]$} \\
\hline & Smooth muscle of rat tail artery & {$[139,140]$} \\
\hline & Catecholamines from bovine chromaffin cells & {$[141,142]$} \\
\hline & Dopamine and GABA from rat brain synaptosomes & [102] \\
\hline & GABA from mouse cortical neurons & [143] \\
\hline & CGRP and/or SP from mouse and rat sensory neurons/afferents & {$[72,144-146]$} \\
\hline \multirow{7}{*}[\mathrm{Ca}^{2+}]{$_{\mathrm{i}}$ increase } & Influx through NCX in Torpedo cholinergic synaptosomes & {$[134,147]$} \\
\hline & Mobilization from internal stores: & \\
\hline & Neuroblastoma x glioma hybrid NG108-15 cells & {$[106,148]$} \\
\hline & Rat skeletal myotubes & [110] \\
\hline & Bovine chromaffin cells & [141] \\
\hline & Influx through TRPA1 in DRG neurons & [111] \\
\hline & Influx through $\mathrm{Ca}_{\mathrm{v}}$ in SH-SY5Y neuroblastoma cells & [72] \\
\hline \multirow{3}{*}{ Modulation of gene expression } & $\begin{array}{c}\text { Upregulation of iNOS and pro-inflammatory cytokines in } \\
\text { RAW } 264.7 \text { macrophages }\end{array}$ & {$[149,150]$} \\
\hline & Gene expression modulation in mouse cortical neurons & {$[114,151]$} \\
\hline & $\begin{array}{l}\text { Expression modulation of genes involved in immune responses and } \\
\text { detoxification in the blood, liver and brain }\end{array}$ & [152-154] \\
\hline
\end{tabular}

\subsection{Neuronal Molecular Targets of CTXs Resulting in Membrane Hyperexcitability}

\subsubsection{Voltage-Gated Sodium Channels $\left(\mathrm{Na}_{\mathrm{v}}\right)$ As the Main Primary Targets}

After being mistakenly identified as anticholinesterases [155,156], CTXs have since been identified as sodium flow-increasing toxins [157]. CTXs are now well known to bind with high affinity and specificity to the "receptor-site 5" (localized to the S6 segment of domain I and 
S5 segment of domain IV) of the alpha subunit of $\mathrm{Na}_{\mathrm{v}}$ channels [158-160], which are highly expressed in excitable cells. Electrophysiological studies have demonstrated that low nanomolar concentrations of CTXs modify the biophysical properties of both tetrodotoxin-sensitive (TTX-s) and tetrodotoxin-resistant (TTX-r) $\mathrm{Na}_{\mathrm{v}}$ channels. Alterations of TTX-s $\mathrm{Na}_{\mathrm{v}}$ properties comprise a shift of the activation threshold voltage to more negative values associated with an impairment of their inactivation process [103,104,109-111,114,161,162]. Although only a few studies have been performed in TTX-r $\mathrm{Na}_{\mathrm{v}}$ expressing preparations like sensory neurons, they have shown that TTX-r $\mathrm{Na}_{\mathrm{v}}$ channels are also targeted by CTXs. Modifications of the TTX-r $\mathrm{Na}_{\mathrm{v}}$ biophysical properties by CTXs include an increase in the recovery rate from inactivation [162] and a shift of the activation voltage-dependence of $\mathrm{Na}_{\mathrm{v}} 1.8$ to more negative values [111]. Using a high-throughput membrane potential assay in HEK293 expressing human $\mathrm{Na}_{\mathrm{v}}$ isoforms activated by P-CTX-1 plus veratridine, recent data showed that the rank order potency of P-CTX- 1 on human $\mathrm{Na}_{\mathrm{V}}$ subtypes was $\mathrm{Na}_{\mathrm{v}} 1.8>\mathrm{Na}_{\mathrm{v}} 1.3>\mathrm{Na}_{\mathrm{v}} 1.1>\mathrm{Na}_{\mathrm{v}} 1.2>\mathrm{Na}_{\mathrm{v}} 1.5>\mathrm{Na}_{\mathrm{v}} 1.7>\mathrm{Na}_{\mathrm{v}} 1.6>\mathrm{Na}_{\mathrm{v}} 1.4$ [112]. The same authors provided electrophysiological evidence that CTXs shifted the activation voltage-dependence of all human $\mathrm{Na}_{\mathrm{v}}$ isoforms to more hyperpolarizing potentials, with a greater impact on $\mathrm{Na}_{\mathrm{v}} 1.8$ and $\mathrm{Na}_{\mathrm{v}} 1.9$ than TTX-s $\mathrm{Na}_{\mathrm{v}}$. The most altered inactivation parameters included a hyperpolarizing shift of the voltage-dependence of steady-state fast inactivation for $\mathrm{Na}_{\mathrm{v}} 1.9$ and $\mathrm{Na}_{\mathrm{v}} 1.2$, and an increase in the inactivation time constant for $\mathrm{Na}_{\mathrm{v}} 1.8$ [112].

As a consequence, CTXs allow opening of the channel at the resting membrane potential and provoke a persistent $\mathrm{Na}^{+}$conductance and a membrane depolarization, followed by spontaneous and repetitive firing in some models [103,104,107,108,111], including sensory neurons (Figure 2). It is worth noting that CTX binds both to resting and inactivated $\mathrm{Na}_{\mathrm{v}}$ with similar affinity, and that during action potentials, the affinity of CTXs for Nav channels is increased, which has been proposed to be due to a channel conformation change [105]. CTX-induced depolarization of numerous excitable cells through activation of their $\mathrm{Na}_{\mathrm{v}}$ channels was shown, including almost all types of peripheral nerves and muscles cell types (see Table 1), except smooth muscle cells on which only indirect depolarization or contraction through $\mathrm{Na}_{\mathrm{v}}$ activation of innervation were shown in the tail artery, vas deferens and ileum $[132,138,139]$. It should be noted that CTXs were 10 to 100 times more potent in stimulating cardiac adrenergic nerves than myocardial cells in guinea pig atria [132].

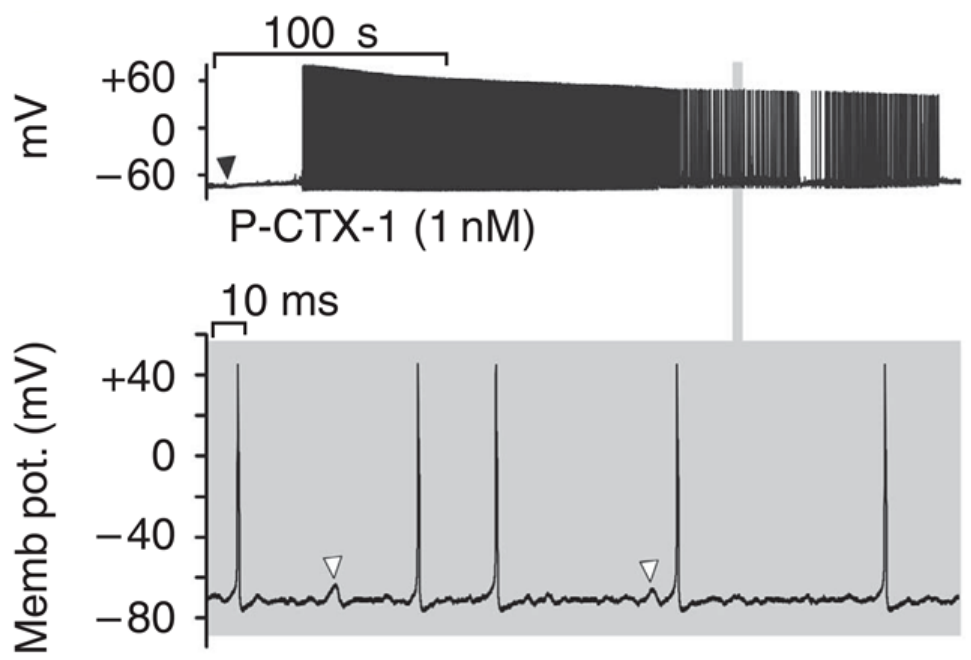

Figure 2. Spontaneous action potential firing induced by P-CTX-1 $(1 \mathrm{nM})$ in cultured mouse dorsal root ganglion neurons. Upper panel: membrane depolarization followed by series of action potentials. Lower panel: expanded view showing membrane potential oscillations frequently followed by action potentials (reprinted from [111] with editor permission). 
Clinical acute and chronic features of CFP suggest that sensory afferents are the preferential targets of CTXs. Adult dorsal root ganglion (DRG) neurons express both TTX-s (mainly $\mathrm{Na}_{\mathrm{v}} 1.6, \mathrm{Na}_{\mathrm{v}} 1.7$ and $\left.\mathrm{Na}_{\mathrm{v}} 1.1\right)$ and TTX-r $\left(\mathrm{Na}_{\mathrm{v}} 1.8\right.$ and $\left.\mathrm{Na}_{\mathrm{v}} 1.9\right)$ [163]. In mice, $\mathrm{Na}_{\mathrm{v}} 1.6$ and $\mathrm{Na}_{\mathrm{v}} 1.7$ are the main isoforms driving P-CTX-1-induced spontaneous dermal pain and action potential firing in cutaneous A-fibers, and cold allodynia is partly mediated by the sensitization to cold of TTX-sensitive A-fibers. Action potential firing in cutaneous and colonic C-fibers predominantly involves $\mathrm{Na}_{\mathrm{v}} 1.8$, which mediates cold allodynia and colonic visceral pain elicited by the toxin. $\mathrm{Na}_{\mathrm{v}} 1.8$ is also involved in the mechanical hypersensitivity induced in rats $[111,112,164]$. These findings are consistent with the roles of these isoforms in the firing properties of nociceptive neurons and cold pain [163,165,166].

The release of the neuropeptide calcitonin-gene related peptide (CGRP) induced by P-CTX-1 in mouse skin-nerve preparations was shown to involve $\mathrm{Na}_{\mathrm{v}} 1.9$ and the combined activation of $\mathrm{Na}_{\mathrm{v}} 1.7$ and $\mathrm{Na}_{\mathrm{v}} 1.1$ [144]. Although the $\mathrm{Na}_{\mathrm{v}}$ isotypes mediating the pruritus induced by CTXs remain to be identified, the roles of $\mathrm{Na}_{\mathrm{v}} 1.7$ and $\mathrm{Na}_{\mathrm{v}} 1.9$ have been revealed in acute itch from other etiologies [167-171]. Interestingly, $\mathrm{Na}_{\mathrm{v}} 1.7$ is required for the release of another neuropeptide, substance P (SP), in the spinal cord from electrically stimulated DRG neurons, and the subsequent wind-up, i.e., increased dorsal horn neuron excitability following repeated C-fiber stimulation [172]. $\mathrm{Na}_{\mathrm{v}} 1.9$ activates at potentials close to the resting membrane potential and leads to a persistent sodium current that amplifies and prolongs the response to subthreshold inputs in DRG neurons, thus increasing their excitability $[163,173]$. Although $\mathrm{Na}_{\mathrm{v}} 1.9$ is mainly expressed in nonpeptidergic sensory neurons, it is also present in a subpopulation of peptidergic neurons [169], and the activation of a low channel density is sufficient to modify the neuronal electrogenic properties $[173,174]$.

\subsubsection{Blockage of Voltage-Gated Potassium Channels $\left(\mathrm{K}_{\mathrm{v}}\right)$}

In addition to their activation of $\mathrm{Na}_{\mathrm{v}}$ channels, CTXs, and especially GTXs, have been shown to inhibit voltage-gated potassium channels $\left(\mathrm{K}_{\mathrm{v}}\right)$, thus further increasing the membrane excitability. Among the CTXs isolated from ciguateric fish, P-CTX-1 partially blocked $\mathrm{K}^{+}$currents in a dose-dependent manner in cultured rat myotubes [110]. P-CTX-1 also blocked $\mathrm{K}_{\mathrm{v}}$ in rat DRG neurons, especially delayed-rectified and A-type potassium channels, without changing the voltage dependence of activation. This effect contributed to the prolonged action potential and afterhyperpolarization induced by the toxin [113].

Gambiertoxins and related toxins produced by Gambierdiscus microalgae (e.g., gambierol) exhibit actions on voltage-gated ion channels that differ from that of the congeners isolated from fish. CTX-4B, which was 50-fold less potent than its metabolite in fish (P-CTX-1) in inducing spontaneous action potentials in myelinated nerve fibers [12], was four-fold more potent than P-CTX-1 at inhibiting $\mathrm{K}_{\mathrm{V}}$ channels, and two-fold more effective in affecting $\mathrm{K}_{\mathrm{v}}$ than $\mathrm{Na}_{\mathrm{v}}$ channels [175]. In mouse taste cells, high concentrations of gambierol failed to activate $\mathrm{Na}_{\mathrm{v}}$ channels, whereas low nanomolar concentrations markedly inhibited $\mathrm{K}_{\mathrm{v}}$ channels $[176,177]$. In contrast, in the same model, CTX-3C did affect $\mathrm{Na}_{\mathrm{v}}$ channels, but it had no effect on $\mathrm{K}_{\mathrm{v}}$ channels [178].

\subsection{Neurocellular Effects of CTXs}

A number of cellular effects induced by CTXs, including swelling, neurosecretion, an increase in intracellular calcium levels and the modulation of gene expression, have been demonstrated. All were found to be secondary to $\mathrm{Na}_{\mathrm{v}}$ activation.

\subsubsection{Cell Swelling}

Nanomolar concentrations of P-CTX-1, C-CTX-1, and CTX-3C induced approximately two-fold swelling of the nodes of Ranvier in frog myelinated nerve fibers. The molecular and cellular events proposed to explain this swelling are an osmotically driven water entry subsequent to the increased intracellular concentration of $\mathrm{Na}^{+}$due to continuous $\mathrm{Na}^{+}$influx through persistently activated $\mathrm{Na}_{\mathrm{V}}$ channels. Indeed, nodal swelling of myelinated nerve fibers was prevented by tetrodotoxin and 
completely prevented and reversed by pretreatment with or the addition of hyperosmolar external solutions of D-mannitol $[104,116,179]$. More recently, this nodal swelling was found to involve both sodium influx and potassium efflux [117]. Interestingly, this swelling also occurred in sensory neurons and was also reversed by hyperosmolar D-mannitol extracellular solutions [118]. Motor nerve terminals and perisynaptic Schwann cell soma of frog neuromuscular junctions (NMJs) exposed to CTXs were also swollen $[115,119,120]$.

These experimental findings are consistent with the swelling of both peripheral and central nervous structures observed in human CFP cases. In two severe cases, edema of myelin fibers, sometimes intra-axonal, or of the adaxonal Schwann cell cytoplasm, were revealed in biopsied sural nerves $[59,121]$. The skin biopsy of a mild CFP case with typical neurocutaneous disorders revealed swelling of intraepidermal nerve fibers 2 months after CTX exposure [70]. Finally, three cases of intramyelinic cytotoxic edema in the corpus callosum revealed by brain MRI were reported [122,123].

In mice experimentally intoxicated with a single dose of CTX, non-myelinated nerves of the enteric nervous system (the myenteric Auerbach plexus and submucosal Meissner plexus) were swollen, as were synapses in the myenteric plexus and vas deferens smooth muscle layers. A swelling of cardiac myocytes was also present, likely resulting from a direct effect (activation of the myocardial $\mathrm{Na}_{\mathrm{v}}$ channels) instead of an indirect action through activation of $\mathrm{Na}_{\mathrm{v}}$ in cardiac autonomic nerves. Surprisingly, swelling also affected erythrocytes in the cardiac tissue [124,125]. However, cell swelling induced by CTXs in nonexcitable cells has also been reported. P-CTX-1 and C-CTX-1 were able to induce frog erythrocyte swelling [126,127]. In mice, repeated CTX exposure for 2 weeks induced the swelling of cardiac myocytes but also endothelial cells lining the heart capillaries [128]. Whether nonexcitable cell swelling by CTXs is a direct effect or a result of a primary effect on neighboring excitable cells remains to be investigated.

\subsubsection{Neuromediator Release Linked to Autonomic Dysfunctions and Sensory Disturbances}

In various models, CTXs have been shown to induce the release of neuromediators (Table 1), primarily neurotransmitters from the autonomic nervous system and, more recently, neuropeptides from sensory neurons. Their release appears to be of great importance in most of the CFP autonomic dysfunctions and sensory disorders.

- Acetylcholine (ACh) release:

A variety of symptoms occurring in both mice and humans, including sweating, salivation, eye watering and diarrhea $[32,44,61,76,180,181]$, suggest a cholinergic syndrome. Although $\mathrm{Na}_{\mathrm{v}}$ channels drive CTX effects, atropine effectively relieves the gastrointestinal and cardiovascular disturbances (i.e., hypotension and/or bradycardia) in humans, experimental animals, and tissues $[57,125,129-133,182,183]$ (see details in Table 1), suggesting the involvement of ACh and the muscarinic receptors. CTX induced diarrhea in mice only at high doses but not very high doses, which cause rapid death. Diarrhea was associated with increased intestinal mucous secretion and epithelial damage, but the underlying mechanisms were not studied [184,185].

In addition, motor nerve terminals of frog NMJs and myenteric nerves in mice were depleted of synaptic vesicles after CTX exposure [119,125]. Direct evidence for ACh release induced by P-CTX-1 has been shown in frog neuromuscular preparations, in which the toxin triggered $\mathrm{Na}_{\mathrm{v}}$-dependent repetitive endplate potentials (e.p.ps), i.e., repetitive action potentials of skeletal muscle fibers caused by repetitive neurotransmitter release from motor nerve terminals [106]. Caribbean C-CTX- $1 \mathrm{Na}_{\mathrm{v}}$-dependently caused ACh release in the same model [120]. These action potentials, which led to spontaneous uncoordinated muscle contractions [106], could be related to the muscle weakness experienced during CFP.

In human volunteers, intracutaneous injection of low nanomolar concentrations of P-CTX-1 in the forearm elicited a striking axon reflex sweating [72]. This reflects the stimulation of efferent cholinergic 
sympathetic skin nerves [186], which is likely responsible for the profuse sweating described in some CFP cases.

- Release of noradrenaline (NAd) and other catecholamines:

With the exception of piloerection, which may result from stimulation of the sympathetic adrenergic cutaneous innervation, the involvement of the autonomous adrenergic system in the CFP syndrome is not obvious. However, a $\mathrm{Na}_{\mathrm{v}}$-dependent CTX-induced NAd release from guinea pig atria has been associated with positive inotropic and chronotropic actions [135]. Further studies conducted in human or guinea pig atrial and papillary muscle preparations demonstrated that the extrasystoles and inotropic effects of CTXs primarily involved an indirect action through NAd released from the cardiac sympathetic innervation, whereas high concentrations directly activated myocardial cells $[105,132,136,137,161]$. The same mechanism, i.e., the $\mathrm{Na}_{\mathrm{v}}$-dependent release of NAd from presynaptic sympathetic nerves, is involved in the contraction of smooth muscle cells of the vas deferens $[130,131,138,187]$ and rat tail artery $[139,140]$. In rat brain synaptosomes and bovine chromaffin cells, CTXs caused a $\mathrm{Na}_{\mathrm{v}}$-dependent release of dopamine [102] and catecholamines [141,142], respectively.

- Neuropeptide release and role of peptidergic neurons in sensory disturbances:

In vitro, $82 \%$ of the mouse DRG neurons that responded to P-CTX-1 were CGRP-positive, whereas $12 \%$ of the responding neurons bound isolectin B4, i.e., were nonpeptidergic neurons [111]. These findings indicate that sensory peptidergic neurons, i.e., neurons expressing neuropeptides including CGRP or substance P (SP), are major targets of CTXs. In vitro, P-CTX-1 elicits a release of CGRP from the murine skin at low nanomolar concentrations [72] with a higher release rate from mouse than rat skin [144]. The latter study demonstrated the involvement of Nav1.9, Nav1.7 and Nav1.1 but not Nav1.8 in CGRP release from mouse skin-nerve preparations. Both CGRP and SP have been demonstrated to be released by P-CTX-2 at $10 \mathrm{nM}$ in a model of sensory neurons cocultured with keratinocytes [145]. Those neuropeptides initiate the so-called cutaneous neurogenic inflammation and contribute to pain and itch [188-190]. In humans, the P-CTX-1-induced neurogenic action on peptidergic sensory fibers was evidenced after intracutaneous injection of concentrations as low as $1 \mathrm{nM}$, that potently induced a long-lasting axon reflex flare [72], which is consistent with the skin rash reported in 20-30\% of CFP cases [191] and the vasodilatory actions of CGRP and SP.

The SP release elicited by P-CTX-2 in cocultured DRG neurons and keratinocytes was recently found to involve the activation of protease-activated receptor-2 (PAR2) [146], a G protein-coupled receptor expressed in peptidergic sensory neurons that plays a role in itch and pain [192-194]. PAR2 activation was at least mediated by the cysteine protease cathepsin S. Interestingly, P-CTX-2 induced a marked $\mathrm{Na}_{\mathrm{v}}$ - and PAR2-dependent increase in intracellular calcium concentration in DRG neurons and also in keratinocytes. Human epidermal keratinocytes, which express $\mathrm{Na}_{\mathrm{V}}$ and are increasingly identified as itch and pain transducers [195-200], are thus directly targeted by CTXs. In the same study, they also strikingly potentiated the neuronal SP release in the coculture. These findings suggest that keratinocytes could contribute to the neurocutaneous effects occurring during CFP.

- Modulation of central neurotransmitter release:

CTXs caused a $\mathrm{Na}_{\mathrm{v}}$-dependent release of $\gamma$-aminobutyric acid (GABA), but not glutamate, in rat brain synaptosomes and mouse cortical neurons $[102,143]$. In rats, P-CTX-1 shifted the balance between excitatory and inhibitory neurotransmitter levels in the motor cortex toward inhibition. This effect was suggested to account for the reduced electroencephalography activity induced in this area [201] and, together with GABA release, to contribute to chronic fatigue, weakness, and depression associated with CFP through increased inhibitory neurotransmission $[143,201]$. 


\subsubsection{Increase in Intracellular Calcium Concentration in Excitable Cells by Multiple Mechanisms}

Exocytosis of neurotransmitter or neuropeptide vesicles is known to be initiated by an increase in intracellular calcium concentration $\left(\left[\mathrm{Ca}^{2+}\right]_{\mathrm{i}}\right)$. Depending on the cellular models, CTXs have been shown to increase $\left[\mathrm{Ca}^{2+}\right]_{i}$ by several mechanisms (reported in Table 1 ).

- $\quad$ Calcium influx through the $\mathrm{Na}^{+} / \mathrm{Ca}^{2+}$ exchanger (NCX):

NCX normally functions to extrude $\mathrm{Ca}^{2+}$ from cells, contributing to cell calcium homeostasis. In Torpedo cholinergic synaptosomes, P-CTX-1 elicited ACh release, which was dependent on external $\mathrm{Na}^{+}$and prevented by $\mathrm{Na}_{\mathrm{v}}$ or NCX blockade [134,147]. This suggests that, as a consequence of the CTX-induced $\mathrm{Na}^{+}$entry, the exchanger reversed its functioning mode to extrude the excessive $\mathrm{Na}^{+}$, leading to $\left[\mathrm{Ca}^{2+}\right]_{\mathrm{i}}$ increase, which in turn triggered $\mathrm{ACh}$ release.

- Calcium mobilization from intracellular stores:

In contrast, no external $\mathrm{Ca}^{2+}$ was required for P-CTX-1 to induce $\mathrm{Na}_{\mathrm{v}}$-dependent repetitive action potentials in frog skeletal muscle fibers through repetitive ACh release from motor nerve terminals [106]. This rules out a mechanism involving $\mathrm{Ca}^{2+}$ influx into nerve endings and suggests that $\mathrm{Na}_{\mathrm{v}}$ activation elicited ACh release through $\mathrm{Ca}^{2+}$ mobilization from internal stores. Similarly, the $\mathrm{Na}_{\mathrm{v}}$-dependent $\left[\mathrm{Ca}^{2+}\right]_{\mathrm{i}}$ increase elicited by P-CTX-1 in mouse neuroblastoma $\times$ rat glioma NG108-15 hybrid cells was mediated by mobilization from $\mathrm{Ca}^{2+}$ internal stores [119]. In these cells, P-CTX-1 prevented the [Ca $\left.{ }^{2+}\right]_{i}$ increase induced by bradykinin, suggesting that the $\mathrm{Ca}^{2+}$ stores mobilized were dependent on inositol triphosphate (IP3) [148]. A similar mechanism was involved in the P-CTX-1-induced depolarization in myotubes from rat skeletal muscle cells, since this was associated with a $\left[\mathrm{Ca}^{2+}\right]_{i}$ increase independent of external $\mathrm{Ca}^{2+}$ and $\mathrm{Na}_{\mathrm{v}}$-dependent transient increase in intracellular IP3 [110]. In bovine chromaffin cells, a $\mathrm{Na}_{\mathrm{v}}$-dependent mobilization from $\mathrm{Ca}^{2+}$ stores contributed to catecholamine secretion, but the stores involved were caffeine-sensitive [141], suggesting the involvement of ryanodine receptors in the P-CTX-1-induced mobilization.

- Calcium influx through transient receptor potential (TRP) channels:

TRP channels are calcium-permeable channels, among which the thermosensors TRP ankyrin 1 (TRPA1) and vanilloid 1 (TRPV1) are expressed in subpopulations of peptidergic sensory neurons and are involved in itch and pain [202]. In mouse DRG neurons, virtually all DRG neurons responding to P-CTX-1 (1 nM) by an increase in $\left[\mathrm{Ca}^{2+}\right]_{i}$ were TRPA1-positive. The $\mathrm{Na}_{\mathrm{v}} 1.8$-dependent sensitization of TRPA1 to cold in C-fibers (Figure 3) contributed to P-CTX-1-induced cold allodynia in mice [111,164].
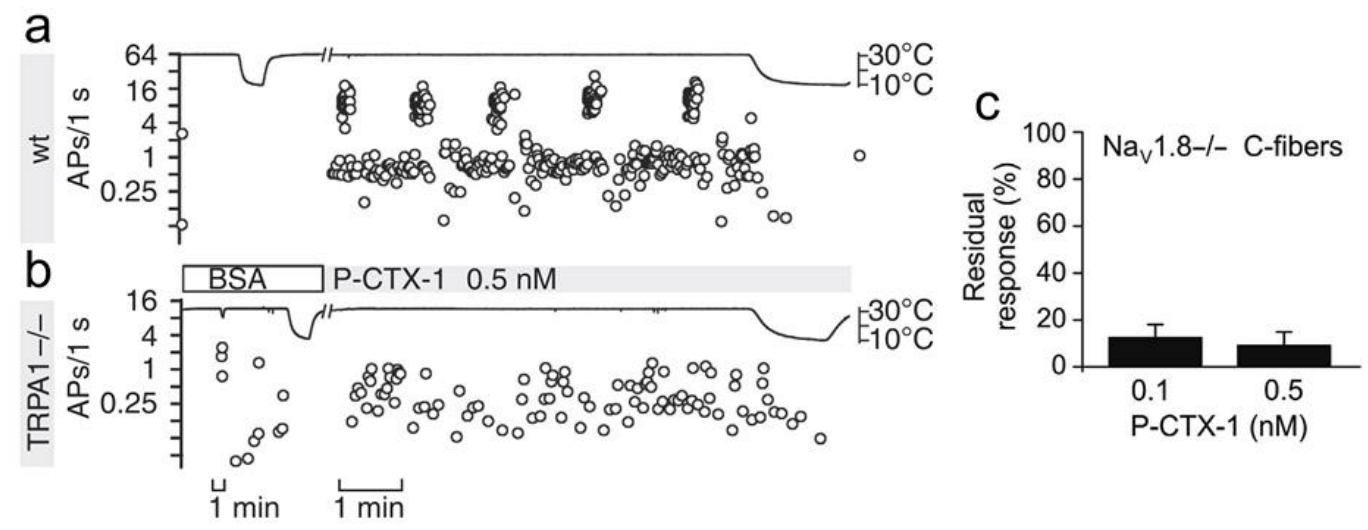

Figure 3. P-CTX-1 sensitizes C-type sensory fibers to cold in a Nav1.8- and TRPA1-dependent manner. Ongoing activity induced by P-CTX-1 $(0.5 \mathrm{nM})$ in single C-fibers recorded from murine skin-saphenous nerve preparations from wild-type (wt) mice (a) and TRPA1-deficient mice (b). Residual cumulative action potentials induced in $5 \mathrm{~min}$ in single C-fibers from Nav1.8-deficient mice (c) compared with wt mice. Reprinted from [111] with editor permission. 
- Calcium influx through voltage-gated calcium channels $\left(\mathrm{Ca}_{\mathrm{V}}\right)$ :

In addition, a $\left[\mathrm{Ca}^{2+}\right]_{i}$ increase involving calcium influx through activated $\mathrm{Ca}_{\mathrm{v}}$ could be a consequence of depolarization, if sufficient, induced by CTXs. Although P-type and N-type $\mathrm{Ca}_{\mathrm{v}}$ have been ruled out in P-CTX-1 elicited ACh release from Torpedo cholinergic synaptosomes [134,147], L-type $\left(\mathrm{Ca}_{\mathrm{v}} 1\right)$ and, to a lesser extent, $\mathrm{N}$-type $\left(\mathrm{Ca}_{\mathrm{v}} 2.2\right)$ channels, were shown to contribute to P-CTX-1-induced calcium responses in SH-SY5Y neuroblastoma cells [72]. Another study showed the ineffectiveness of $\mathrm{L}$ - and T-type $\mathrm{Ca}_{\mathrm{v}}$ antagonists in preventing the P-CTX-1-induced CGRP release from mouse skin flaps, despite the reduction of the residual CGRP release after $\mathrm{Na}_{\mathrm{v}}$ blockage [144].

\subsubsection{Modulation of Gene Expression}

As a second intracellular messenger, $\left[\mathrm{Ca}^{2+}\right]_{\mathrm{i}}$ increase is able to initiate intracellular signaling pathways and lead to gene transcription. In yeast cells, CTX-3C and toxic Gambierdiscus extracts elicited a significant $\left[\mathrm{Ca}^{2+}\right]_{i}$ increase and subsequent activation of the calcineurin signaling pathway [203], which contributes to transcriptional regulation in yeast and other eukaryotic cells. In RAW 264.7 macrophages, P-CTX-1 at low nanomolar concentrations induced the upregulation of inducible nitric oxide synthase (iNOS), tumor necrosis factor- $\alpha$ (TNF- $\alpha$ ), interleukin (IL) IL-1 $\beta$, IL-6 and IL-10 [149,150]. In mouse primary cortical neurons, CTX-3C exposure induced a $\mathrm{Na}_{\mathrm{v}}{ }^{-}$and time-dependent expression modulation of a number of genes, including upregulation of the immediate early genes Arc and Egr and downregulation of the glutamate NMDA and AMPA receptors [114,151]. In mice, exposure to a high dose (median lethal dose) of P-CTX-1 downregulated immediate early genes and modulated the expression of genes involved in immune responses and detoxification in the blood, liver and brain [152-154]. In the brain, both downregulation of immediate early genes and anti-inflammatory gene signature have been proposed as neuroprotective mechanisms correlating with the hypothermia induced by P-CTX-1 [153]. Based on a whole blood transcriptomic profiling study, the activation of inflammatory pathways, as well as genetic variants of the adaptive immune system, were suggested to be involved in the persistence of CFP disturbances [96].

\subsection{Neurophysiological and Nerve Histological Studies}

Very few neurophysiological and histological studies have been performed in CFP cases. Most of them were severe forms of CFP, in which examinations revealed signs of demyelination. Rare studies have been carried out in experimentally intoxicated animals.

Allsop et al. [59] reported 3 CFP cases with central neurological disturbances in addition to marked sensory characteristic symptoms (severe cases). Neurophysiological studies performed on a peripheral mixed nerve (median nerve) revealed slowed motor conduction velocities in all cases. A more detailed study performed in one case also showed a slowing in sensory conduction velocity, a decreased sensory amplitude and delayed distal and F wave latencies, suggesting an altered myelin sheath. This was confirmed by a biopsy of the sural nerve, which revealed a striking edema in the adaxonal layer of the Schwann cell cytoplasm, with axonal compression and vesicular degeneration of the myelin.

A more recent study performed in a more typical CFP case reported no neurophysiological abnormalities in nerve conduction and needle electromyography studies. A skin biopsy from the distal leg, carried out 2 months after intoxication, revealed that the density of the intraepidermal nerve fibers was normal, but diffuse axonal swellings were observed [70].

In two cases diagnosed with acute polyradiculoneuritis after CFP, electromyogram recordings showed prolonged distal latencies, a decreased motor conduction velocity and absence of $\mathrm{F}$ wave. The muscle biopsy revealed a relative hypomyelination at the Ranvier node level [204].

A nerve conduction study performed in vivo in rat mixed and motor nerves of the ventral coccygeal nerve of the tail showed that CTXs induced a slowing of conduction velocities and delayed $F$ wave responses, decreased action potential amplitudes, a prolonged absolute refractory period, and an increase in both the magnitude and duration of the supernormal period [205]. The same authors 
performed a neurophysiological study in 15 human cases of CFP presenting with acute gastrointestinal and sensory disturbances but also unusual motor disorders in the extremities. The sensory (sural) and motor (peroneal) conduction velocities were both decreased, but only significantly so in the sensory nerve. The action potential amplitude was increased only for the motor nerve. Absolute and relative refractory periods were markedly prolonged for both nerves [206].

A complete neurophysiological evaluation was performed in four cases of mild CFP with the usual clinical features. Motor and sensory conduction velocities in the peroneal and right median nerves, repetitive nerve stimulation of the right median nerve, as well as sudomotor sympathetic skin responses were normal. Only abnormalities of neuromuscular excitability assessed by a latent tetany test were noted [207].

An interesting axonal excitability study was performed in two patients presenting with relapsing sensory disturbances many years after the acute phase of CFP [91]. The results obtained by stimulating the median nerve revealed no abnormalities of axonal $\mathrm{Na}_{\mathrm{v}}$ functions in both motor and sensory nerves. As noticed by the authors, given that the patients were asymptomatic at the time of the study, abnormalities during the period when the intermittent recurrent symptoms were occurring cannot be excluded.

As pointed out in the latter study, axonal excitability studies as well as conventional nerve conduction studies have investigated the functions of large-diameter myelinated but not small-diameter unmyelinated or thinly myelinated fibers, i.e., autonomic and sensory A $\delta$ - and C-fibers, which are mainly targeted by CTXs. Abnormalities found in these neurophysiological studies may explain the muscular weakness or fatigability occurring during CFP but not the more common symptoms, including paresthesia, cold dysesthesia or pruritus involving the $\mathrm{C}$ - or $\mathrm{A} \delta$-fibers.

\subsection{Unsolved Issues: Prevalence and Persistence of Sensory Disturbances}

Toxicokinetic data indicate that CTXs are readily absorbed and largely distributed to the body tissues, including the muscles, liver and brain (see [15] for details), likely due to their lipophilic nature. Although $\mathrm{Na}_{\mathrm{v}}$ channels are highly expressed in all excitable cells, the predominance of sensory disorders suggests that CTXs particularly target somatosensory nerves/neurons. The time course of sensory disturbances (i.e., perioral paresthesia, abdominal pain and then pruritus and pain affecting the whole body including the face) [63] suggests an initial impact on trigeminal and enteric sensory afferents, then DRG and trigeminal sensory nerves/neurons. This is compatible with contact with/absorption through the mouth and intestine mucosa followed by distribution to the DRG and trigeminal fibers/neurons. In contrast to the neurons of the central nervous system, cell soma in the peripheral nervous system are located in ganglia and are not protected by blood-brain or blood-spinal cord barriers. Dorsal root and trigeminal ganglia are highly vascularized by fenestrated blood vessels, features that allow the preferential supply or even accumulation of a variety of neurotoxicants, favoring sensory neuropathy [208]. Likewise, peripheral nerves are partially protected by the blood-nerve barrier, which exhibits selective permeability. These toxicokinetic factors could contribute to the preferential sensory toxicity of CTXs. Consistent with this, peripheral nerves were the main tissues in which P-CTX-1 was quantified $2 \mathrm{~h}$ after intraperitoneal exposure, ahead of the intestine, kidneys, stomach, liver, heart and muscles [209].

Other toxicokinetic factors, including the quasi-irreversible binding of CTXs to $\mathrm{Na}_{\mathrm{v}}$ and a potential release from binding sites (tissue or plasma proteins or lipoproteins), likely contribute to the persistence and reoccurrence of CFP sensory disorders. P-CTX-1 was indeed still detected in peripheral nerves 2 months after exposure [209]. However, CFP sensory disturbances can persist and/or reoccur many months or even years (see Section 2.3). The mechanisms involved remain to be clarified. In mice, the alterations induced in the anterior cingulate cortex one day after oral administration of a high dose (median lethal dose) of P-CTX-1 (neuronal spontaneous firings, an enhanced response to visceral noxious stimulation, synaptic potentiation, blockage of the induction of long-term potentiation, and reactive astrogliosis) were resolved by day 7 [210]. However, another study showed a recurrent 
motor strength deficit associated with neuronal apoptosis, reduced spontaneous firing rate and astrogliosis in the motor cortex 4 to 6 months after intraperitoneal administration of twice the same dose. The pinprick sensory test, which assesses functions of subpopulations of A-fibers and to a lesser extent C-fibers, showed no change in mice during 4 months following P-CTX-1 exposure compared with mice exposed to P-CTX-1 vehicle [211].

\section{Treatment of Ciguatera Poisoning}

So far, no clinically validated cure exists for CFP. Only symptomatic treatments are delivered to patients suffering from ciguateric signs, consisting of analgesics against muscle and joint pain and anti-histaminic drugs for the pruritus. Atropine appears to be effective in relieving the digestive and cardiovascular disorders $[57,183]$.

In the Pacific, herbal remedies traditionally used to treat CFP [212,213] are still used currently [90]. Some of them were experimentally studied and showed:

- $\quad$ to speed up the recovery of mice from weight loss after intraperitoneal injection of ciguatoxic fish extract [214,215];

- $\quad$ to prevent and reverse the P-CTX-1-induced increase in nodal membrane excitability and swelling of frog myelinated axons [216];

- $\quad$ to inhibit the $\mathrm{Na}_{\mathrm{v}}$ activation-based cytotoxicity [217] as well as to inhibit the LPS-induced nitric oxide production in RAW 264.7 macrophages [218,219], since P-CTX-1 was shown to induce such a production $[127,149]$.

Some efficacy in the four aforementioned models was shown for Heliotropium foertherianum (formerly Argusia argentea, Boraginaceae), one of the most popular remedies in Polynesia and Melanesia but also in the Japan islands [214,216-218,220]. In addition, the plant extract and one of its active principles, rosmarinic acid, were able to displace a brevetoxin (a functional CTX analogue) from its $\mathrm{Na}_{\mathrm{V}}$ binding site [221]. Rosmarinic acid also prevented the cytotoxicity induced by CTXs in human primary neurons from mixed brain cultures [222].

Some drugs were reported in a small handful of occasional cases to successfully relieve neurological symptoms, although they were never studied in randomized trials:

- Low dose of the tricyclic antidepressant amitriptyline during the first few days have shown a variable beneficial effect on some long-lasting neurological disturbances (paresthesia, myalgia, pruritus, headache) and bradycardia, and no effect on cold dysesthesia [223-227]. Experimentally, amitriptyline was ineffective in reducing cold allodynia induced in rats after intraplantar exposure to P-CTX-1 [72].

- Lidocaine is a local anesthetic that inhibits $\mathrm{Na}_{\mathrm{v}}$ channels. In frog myelinated axons, lidocaine reversed the membrane hyperexcitability and axonal swelling induced by P-CTX-1 [12,216]. In vivo, it countered some cardiovascular effects and some peripheral nerve disturbances elicited by ciguatoxic extracts in cats [228] and in rats [229], respectively. In humans, beneficial effects on the persistent neurological signs were obtained in 3 patients by using the orally effective local anesthetic tocainide [225].

- Antiepileptic gabapentinoid drugs, including gabapentin [230] and pregabalin [231], were anecdotally but successfully used to treat persisting sensory disturbances in ciguatera patients.

- Nifedipine, a calcium channel antagonist, has successfully improved headache with no effect on myalgia, pruritus or cold dysesthesia [224]. It partially inhibited the P-CTX-1-induced calcium response in SH-SY5Y human neuroblastoma cells but failed to alter the cold allodynia induced by P-CTX-1 in rats [72].

The potential efficacy of other compounds has been reported in experimental studies. Brevenal, a polyether compound produced together with brevetoxins by Karenia brevis, is an antagonist of the binding of CTXs to $\mathrm{Na}_{\mathrm{v}}[232,233]$. It inhibited the P-CTX-1-induced catecholamine release from 
chromaffin cells $[141,142]$. Two monoclonal anti-CTX-3C antibodies were shown to synergistically neutralize in vitro and in vivo the toxic effects induced by this congener [234].

The most frequently used treatment in severe hospitalized cases is early intravenous perfusion of hypertonic D-mannitol ( $1 \mathrm{~g} / \mathrm{kg}$ body weight as a $20 \%$ solution over $30-45 \mathrm{~min})$, which is commonly used to reduce increased intracranial pressure associated with brain edema. Despite an efficacy demonstrated experimentally on nerve swelling and hyperexcitability $[104,116,118,179,216]$, and in human cases [235-237], this treatment did not show an increased benefit relative to normal saline in a double-blind randomized trial [238] or any benefit when administered a few days after intoxication [239]. In addition, this treatment can worsen dehydration caused by the digestive disorders (diarrhea, vomiting) and patients should therefore be carefully monitored.

\section{Conclusions}

CFP is an underreported disease with a complex and polymorphous symptomatology, and the unique feature of a possible persistence or recurrence of disturbances long after the ciguateric meal. A precise knowledge of the "acute" and "chronic" clinical signs following acute exposure to CTX, among which sensory disturbances predominate, is necessary for CFP to be better recognized. This will allow for a better assessment of the global incidence of CFP as well as for providing appropriate medical support for intoxicated patients. Pathophysiological data indicate that the peripheral neurological and nonneurological symptoms arise from disorders of the sensory or autonomic nerves. The autonomic dysfunction-based disorders, including digestive and cardiovascular symptoms, resolve spontaneously or are treated effectively. Effective treatment to relieve the persistent sensory disturbances is lacking. The molecular mediators involved in their pathophysiology, such as $\mathrm{Na}_{\mathrm{v}} 1.8$ and TRPA1 in cold allodynia, could be the basis for developing specific therapeutics.

Funding: This review received no external funding.

Conflicts of Interest: The authors declare no conflict of interest.

\section{References}

1. Chinain, M.; Germain, M.; Deparis, X.; Pauillac, S.; Legrand, A.-M. Seasonal abundance and toxicity of the dinoflagellate Gambierdiscus spp. (Dinophyceae), the causative agent of ciguatera in Tahiti, French Polynesia. Mar. Biol. 1999, 135, 259-267. [CrossRef]

2. Litaker, R.W.; Vandersea, M.W.; Faust, M.A.; Kibler, S.R.; Nau, A.W.; Holland, W.C.; Chinain, M.; Holmes, M.J.; Tester, P.A. Global distribution of ciguatera causing dinoflagellates in the genus Gambierdiscus. Toxicon 2010, 56, 711-730. [CrossRef]

3. Leung, P.T.Y.; Yan, M.; Lam, V.T.T.; Yiu, S.K.F.; Chen, C.-Y.; Murray, J.S.; Harwood, D.T.; Rhodes, L.L.; Lam, P.K.S.; Wai, T.-C. Phylogeny, morphology and toxicity of benthic dinoflagellates of the genus Fukuyoa (Goniodomataceae, Dinophyceae) from a subtropical reef ecosystem in the South China Sea. Harmful Algae 2018, 74, 78-97. [CrossRef]

4. Satake, M.; Ishibashi, Y.; Legrand, A.M.; Yasumoto, T. Isolation and structure of ciguatoxin-4A, a new ciguatoxin precursor, from cultures of dinoflagellate Gambierdiscus toxicus and Parrotfish Scarus gibbus. Biosci. Biotechnol. Biochem. 1997, 60, 2103-2105. [CrossRef]

5. Yogi, K.; Sakugawa, S.; Oshiro, N.; Ikehara, T.; Sugiyama, K.; Yasumoto, T. Determination of toxins involved in ciguatera fish poisoning in the Pacific by LC/MS. J. AOAC Int. 2014, 97, 398-402. [CrossRef]

6. Murata, M.; Legrand, A.M.; Ishibashi, Y.; Fukui, M.; Yasumoto, T. Structures and configurations of ciguatoxin from the Moray Eel Gymnothorax javanicus and its likely precursor from the dinoglagellate Gambierdiscus toxicus. J. Am. Chem. Soc. 1990, 112, 4380-4386. [CrossRef]

7. Satake, M.; Murata, M.; Yasumoto, T. The structure of CTX3C, a ciguatoxin congener isolated from cultured Gambierdiscus toxicus. Tetrahedron Lett. 1993, 34, 1979-1980. [CrossRef]

8. Yogi, K.; Oshiro, N.; Inafuku, Y.; Hirama, M.; Yasumoto, T. Detailed LC-MS/MS analysis of ciguatoxins revealing distinct regional and species characteristics in fish and causative alga from the Pacific. Anal. Chem. 2011, 83, 8886-8891. [CrossRef] [PubMed] 
9. Soliño, L.; Costa, P.R. Global impact of ciguatoxins and ciguatera fish poisoning on fish, fisheries and consumers. Environ. Res. 2020, 182, 109111. [CrossRef] [PubMed]

10. Lewis, R.J.; Holmes, M.J. Origin and transfer of toxins involved in ciguatera. Comp. Biochem. Physiol. Part C Comp. Pharmacol. Toxicol. 1993, 106, 615-628. [CrossRef]

11. Lewis, R.J.; Sellin, M.; Poli, M.A.; Norton, R.S.; MacLeod, J.K.; Sheil, M.M. Purification and characterization of ciguatoxins from moray eel (Lycodontis javanicus, Muraenidae). Toxicon 1991, 29, 1115-1127. [CrossRef]

12. Benoit, E.; Legrand, A.-M. Gambiertoxin-induced modifications of the membrane potential of myelinated nerve fibres. Mem. Qld. Mus. 1994, 34, 461-464.

13. Pawlowiez, R.; Darius, H.T.; Cruchet, P.; Rossi, F.; Caillaud, A.; Laurent, D.; Chinain, M. Evaluation of seafood toxicity in the Australes archipelago (French Polynesia) using the neuroblastoma cell-based assay. Food Addit. Contam. Part A Chem. Anal. Control Expo. Risk Assess. 2013, 30, 567-586. [CrossRef]

14. Roue, M.; Darius, H.T.; Picot, S.; Ung, A.; Viallon, J.; Gaertner-Mazouni, N.; Sibat, M.; Amzil, Z.; Chinain, M. Evidence of the bioaccumulation of ciguatoxins in giant clams (Tridacna maxima) exposed to Gambierdiscus spp. cells. Harmful Algae 2016, 57, 78-87. [CrossRef] [PubMed]

15. FAO; WHO. Report of the Expert Meeting on Ciguatera Poisoning: Rome, 19-23 November 2018; Food Safety and Quality Series; FAO and WHO: Rome, Italy, 2020; ISBN 978-92-5-132518-6.

16. Lehane, L.; Lewis, R.J. Ciguatera: Recent advances but the risk remains. Int. J. Food Microbiol. 2000, 61, 91-125. [CrossRef]

17. Hossen, V.; Solino, L.; Leroy, P.; David, E.; Velge, P.; Dragacci, S.; Krys, S.; Flores Quintana, H.; Diogene, J. Contribution to the risk characterization of ciguatoxins: LOAEL estimated from eight ciguatera fish poisoning events in Guadeloupe (French West Indies). Environ. Res 2015, 143, 100-108. [CrossRef] [PubMed]

18. Zhang, Z.; Zhang, C.; Luan, W.; Li, X.; Liu, Y.; Luo, X. Ultrasensitive and accelerated detection of ciguatoxin by capillary electrophoresis via on-line sandwich immunoassay with rotating magnetic field and nanoparticles signal enhancement. Anal. Chim. Acta 2015, 888, 27-35. [CrossRef]

19. Tsumuraya, T.; Sato, T.; Hirama, M.; Fujii, I. Highly Sensitive and Practical Fluorescent Sandwich ELISA for Ciguatoxins. Anal. Chem. 2018, 90, 7318-7324. [CrossRef]

20. Tsumuraya, T.; Hirama, M. Rationally Designed Synthetic Haptens to Generate Anti-Ciguatoxin Monoclonal Antibodies, and Development of a Practical Sandwich ELISA to Detect Ciguatoxins. Toxins 2019, 11, 533. [CrossRef]

21. Pasinszki, T.; Lako, J.; Dennis, T.E. Advances in Detecting Ciguatoxins in Fish. Toxins 2020, 12, 494. [CrossRef]

22. Graber, N.; Stavinsky, F.; Hoffman, R.; Button, J.; Clark, N.; Martin, S.; Robertson, A.; Hustedt, J. Centers for Disease Control and Prevention (CDC) Ciguatera fish poisoning-New York City, 2010-2011. MMWR Morb. Mortal. Wkly. Rep. 2013, 62, 61-65.

23. Hamilton, B.; Whittle, N.; Shaw, G.; Eaglesham, G.; Moore, M.R.; Lewis, R.J. Human fatality associated with Pacific ciguatoxin contaminated fish. Toxicon 2010, 56, 668-673. [CrossRef] [PubMed]

24. Pottier, I.; Vernoux, J.P.; Jones, A.; Lewis, R.J. Analysis of toxin profiles in three different fish species causing ciguatera fish poisoning in Guadeloupe, French West Indies. Food Addit. Contam. 2002, 19, 1034-1042. [CrossRef] [PubMed]

25. Wong, C.-K.; Hung, P.; Lo, J.Y.C. Ciguatera fish poisoning in Hong Kong-A 10-year perspective on the class of ciguatoxins. Toxicon 2014, 86, 96-106. [CrossRef] [PubMed]

26. Hardison, D.R.; Holland, W.C.; McCall, J.R.; Bourdelais, A.J.; Baden, D.G.; Darius, H.T.; Chinain, M.; Tester, P.A.; Shea, D.; Flores Quintana, H.A.; et al. Fluorescent Receptor Binding Assay for Detecting Ciguatoxins in Fish. PLoS ONE 2016, 11, e0153348. [CrossRef]

27. Estevez, P.; Sibat, M.; Leão-Martins, J.M.; Reis Costa, P.; Gago-Martínez, A.; Hess, P. Liquid Chromatography Coupled to High-Resolution Mass Spectrometry for the Confirmation of Caribbean Ciguatoxin-1 as the Main Toxin Responsible for Ciguatera Poisoning Caused by Fish from European Atlantic Coasts. Toxins 2020, 12, 267. [CrossRef]

28. Bottein Dechraoui, M.Y.; Wang, Z.; Turquet, J.; Chinain, M.; Darius, T.; Cruchet, P.; Radwan, F.F.; Dickey, R.W.; Ramsdell, J.S. Biomonitoring of ciguatoxin exposure in mice using blood collection cards. Toxicon 2005, 46, 243-251. [CrossRef] 
29. Dechraoui Bottein, M.-Y.; Wang, Z.; Ramsdell, J.S. Toxicokinetics of the ciguatoxin P-CTX-1 in rats after intraperitoneal or oral administration. Toxicology 2011, 284, 1-6. [CrossRef]

30. Matta, J.; Navas, J.; Milad, M.; Manger, R.; Hupka, A.; Frazer, T. A pilot study for the detection of acute ciguatera intoxication in human blood. J. Toxicol. Clin. Toxicol. 2002, 40, 49-57. [CrossRef]

31. Vernoux, J.P.; Lewis, R.J. Isolation and characterisation of Caribbean ciguatoxins from the horse-eye jack (Caranx latus). Toxicon Off. J. Int. Soc. Toxinol. 1997, 35, 889-900. [CrossRef]

32. Bagnis, R.; Kuberski, T.; Laugier, S. Clinical observations on 3009 cases of ciguatera (fish poisoning) in the South Pacific. Am. J. Trop. Med. Hyg. 1979, 28, 1067-1073. [CrossRef] [PubMed]

33. Oshiro, N.; Yogi, K.; Asato, S.; Sasaki, T.; Tamanaha, K.; Hirama, M.; Yasumoto, T.; Inafuku, Y. Ciguatera incidence and fish toxicity in Okinawa, Japan. Toxicon 2010, 56, 656-661. [CrossRef] [PubMed]

34. Wong, C.K.; Hung, P.; Lee, K.L.; Mok, T.; Chung, T.; Kam, K.M. Features of ciguatera fish poisoning cases in Hong Kong 2004-2007. Biomed. Environ. Sci. 2008, 21, 521-527. [CrossRef]

35. Pottier, I.; Vernoux, J.P.; Lewis, R.J. Ciguatera fish poisoning in the Caribbean islands and Western Atlantic. In Reviews of Environmental Contamination and Toxicology; Ware, G.W., Nigg, H.N., Eds.; Springer: Tuscon, Arizona, 2001; pp. 99-141.

36. Quod, J.P.; Turquet, J. Ciguatera in Réunion Island (SW Indian Ocean): Epidemiology and clinical patterns. Toxicon 1996, 34, 779-785. [CrossRef]

37. Lewis, R.J.; Jones, A. Characterization of ciguatoxins and ciguatoxin congeners present in ciguateric fish by gradient reverse-phase high-performance liquid chromatography/mass spectrometry. Toxicon 1997, 35, 159-168. [CrossRef]

38. Pottier, I.; Hamilton, B.; Jones, A.; Lewis, R.J.; Vernoux, J.P. Identification of slow and fast-acting toxins in a highly ciguatoxic barracuda (Sphyraena barracuda) by HPLC/MS and radiolabelled ligand binding. Toxicon 2003, 42, 663-672. [CrossRef] [PubMed]

39. Pottier, I.; Vernoux, J.-P.; Jones, A.; Lewis, R.J. Characterisation of multiple Caribbean ciguatoxins and congeners in individual specimens of horse-eye jack (Caranx latus) by high-performance liquid chromatography/mass spectrometry. Toxicon 2002, 40, 929-939. [CrossRef]

40. Hamilton, B.; Hurbungs, M.; Vernoux, J.-P.; Jones, A.; Lewis, R.J. Isolation and characterisation of Indian Ocean ciguatoxin. Toxicon 2002, 40, 685-693. [CrossRef]

41. Hamilton, B.; Hurbungs, M.; Jones, A.; Lewis, R.J. Multiple ciguatoxins present in Indian Ocean reef fish. Toxicon 2002, 40, 1347-1353. [CrossRef]

42. Fleming, L.E.; Baden, D.G.; Bean, J.A.; Weisman, R.; Blythe, D.G. Marine Seafood Toxin Diseases: Issues in Epidemiology and Community Outreach. In Harmful Algae, Proceedings of the VIII International Conference on Harmful Algae, Vigo, Spain, 25-29 June 1997; Xunta de Galicia and Intergovernmental Oceanographic Commission of UNESCO: Galicia, Spain, 1998; pp. 245-248.

43. Ansdell, V.E. Food Poisoning from Marine Toxins. In CDC Yellow Book 2018: Health Information for International Travel; Oxford University Press: New York, NY, USA, 2017; pp. 77-81. ISBN 978-0-19-062861-1.

44. Bagnis, R. Clinical aspects of ciguatera (fish poisoning) in French Polynesia. Hawaii Med. J. 1968, $28,25-28$.

45. Rongo, T.; Van Woesik, R. Ciguatera poisoning in Rarotonga, southern Cook Islands. Harmful Algae 2011, 10, 345-355. [CrossRef]

46. Skinner, M.P.; Brewer, T.D.; Johnstone, R.; Fleming, L.E.; Lewis, R.J. Ciguatera fish poisoning in the Pacific Islands (1998 to 2008). PLoS Negl. Trop. Dis. 2011, 5, e1416. [CrossRef] [PubMed]

47. McKee, D.B.; Fleming, L.E.; Tamer, R.; Weisman, R.; Blythe, D. Physician diagnosis and reporting of ciguatera fish poisoning in an endemic area. In Harmful Algal Blooms 2000; Hallegraeff, G.M., Blackburn, S.I., Bolch, C.J., Lewis, R.J., Eds.; Intergovernmental Oceanographic Commission of UNESCO: Paris, France, 2001; pp. 451-453.

48. Lange, W.R.; Snyder, F.R.; Fudala, P.J. Travel and Ciguatera Fish Poisoning. Arch. Intern. Med. 1992, 152, 2049-2053. [CrossRef] [PubMed]

49. De Haro, L.; Pommier, P.; Valli, M. Emergence of imported ciguatera in Europe: Report of 18 cases at the Poison Control Centre of Marseille. J. Toxicol. Clin. Toxicol. 2003, 41, 927-930. [CrossRef] [PubMed]

50. Glaizal, M.; Tichadou, L.; Drouet, G.; Hayek-Lanthois, M.; De Haro, L. Ciguatera contracted by French tourists in Mauritius recurs in Senegal. Clin. Toxicol. 2011, 49, 767. [CrossRef] [PubMed] 
51. Mattei, C.; Vetter, I.; Eisenblätter, A.; Krock, B.; Ebbecke, M.; Desel, H.; Zimmermann, K. Ciguatera fish poisoning: A first epidemic in Germany highlights an increasing risk for European countries. Toxicon 2014, 91, 76-83. [CrossRef]

52. Tester, P.A.; Feldman, R.L.; Nau, A.W.; Kibler, S.R.; Wayne Litaker, R. Ciguatera fish poisoning and sea surface temperatures in the Caribbean Sea and the West Indies. Toxicon 2010, 56, 698-710. [CrossRef]

53. Gingold, D.B.; Strickland, M.J.; Hess, J.J. Ciguatera fish poisoning and climate change: Analysis of National Poison Center Data in the United States, 2001-2011. Environ. Health Perspect. 2014, 122, 580-586. [CrossRef]

54. Rhodes, L.L.; Smith, K.F.; Murray, J.S.; Nishimura, T.; Finch, S.C. Ciguatera Fish Poisoning: The Risk from an Aotearoa/New Zealand Perspective. Toxins 2020, 12, 50. [CrossRef]

55. Rodriguez, F.; Fraga, S.; Ramilo, I.; Rial, P.; Figueroa, R.I.; Riobo, P.; Bravo, I. Canary Islands (NE Atlantic) as a biodiversity "hotspot" of Gambierdiscus: Implications for future trends of ciguatera in the area. Harmful Algae 2017, 67, 131-143. [CrossRef]

56. Ruff, T.A.; Lewis, R.J. Clinical aspects of ciguatera: An overview. Mem. Qld. Mus. 1994, 34, 609-619.

57. Russell, F.E. Ciguatera poisoning: A report of 35 cases. Toxicon 1975, 13, 383-385. [CrossRef]

58. Morris, J.G.; Lewin, P.; Hargrett, N.T.; Smith, C.W.; Blake, P.A.; Schneider, R. Clinical features of ciguatera fish poisoning: A study of the disease in the US Virgin Islands. Arch. Intern. Med. 1982, 142, 1090-1092. [CrossRef] [PubMed]

59. Allsop, J.L.; Martini, L.; Lebris, H.; Pollard, J.; Walsh, J.; Hodgkinson, S. Neurologic manifestations of ciguatera. 3 cases with a neurophysiologic study and examination of one nerve biopsy. Rev. Neurol. 1986, 142, 590-597. [PubMed]

60. Bagnis, R.A.; Legrand, A.-M.; Cameron, J. Clinical features on 12,890 cases of ciguatera (fish poisoning) in French Polynesia. In Progress in Venom and Toxin Research, Proceedings of the First Asia-Pacific Congress on Animal, Plant and Microbial Toxins, Singapore, 24-27 June 1987; Gopalakrishnakone, P., Tan, C.K., Eds.; Faculty of Medicine, National University of Singapore: Singapore, 1987; pp. 372-384. ISBN 978-9971-62-152-0.

61. Kodama, A.M.; Hokama, Y. Variations in symptomatology of ciguatera poisoning. Toxicon 1989, $27,593-595$. [CrossRef]

62. Geller, R.J.; Olson, K.R.; Senécal, P.E. Ciguatera fish poisoning in San Francisco, California, caused by imported barracuda. West. J. Med. 1991, 155, 639-642. [PubMed]

63. Zimmermann, K.; Eisenblätter, A.; Vetter, I.; Ebbecke, M.; Friedemann, M.; Desel, H. Vergiftung durch Tropenfisch: Ciguatera-Epidemie in Deutschland. Dtsch. Med. Wochenschr. 2015, 140, 125-130. [CrossRef]

64. Gillespie, N.C.; Lewis, R.J.; Pearn, J.H.; Bourke, A.T.; Holmes, M.J.; Bourke, J.B.; Shields, W.J. Ciguatera in Australia. Occurrence, clinical features, pathophysiology and management. Med. J. Aust. 1986, 145, 584-590. [CrossRef]

65. Chan, T. Large Outbreaks of Ciguatera after Consumption of Brown Marbled Grouper. Toxins 2014, 6, 2041-2049. [CrossRef]

66. Chan, T.Y.K. Lengthy persistence of ciguatoxin in the body. Trans. R. Soc. Trop. Med. Hyg. 1998, 92, 662. [CrossRef]

67. Katz, A.R.; Terrell-Perica, S.; Sasaki, D.M. Ciguatera on Kauai: Investigation of factors associated with severity of illness. Am. J. Trop. Med. Hyg. 1993, 49, 448-454. [CrossRef]

68. Friedman, M.A.; Fernandez, M.; Backer, L.C.; Dickey, R.W.; Bernstein, J.; Schrank, K.; Kibler, S.; Stephan, W.; Gribble, M.O.; Bienfang, P.; et al. An Updated Review of Ciguatera Fish Poisoning: Clinical, Epidemiological, Environmental, and Public Health Management. Mar. Drugs 2017, 15, 72. [CrossRef]

69. Cameron, J.; Capra, M.F. The basis of the paradoxical disturbance of temperature perception in ciguatera poisoning. J. Toxicol. Clin. Toxicol. 1993, 31, 571-579. [CrossRef]

70. Ruiz, M.; Lombardi, R.; Salvalaggio, A.; Campagnolo, M.; Castellani, F.; Rondinone, R.; Lauria, G.; Briani, C. A case of Ciguatera poisoning with paradoxical dysaesthesia and degenerative features at skin biopsy. J. Neurol. Sci. 2019, 403, 112-113. [CrossRef]

71. Davis, K.D.; Pope, G.E. Noxious cold evokes multiple sensations with distinct time courses. Pain 2002, 98, 179-185. [CrossRef]

72. Zimmermann, K.; Deuis, J.R.; Inserra, M.C.; Collins, L.S.; Namer, B.; Cabot, P.J.; Reeh, P.W.; Lewis, R.J.; Vetter, I. Analgesic treatment of ciguatoxin-induced cold allodynia. Pain 2013, 154, 1999-2006. [CrossRef] 
73. Eisenblatter, A.; Lewis, R.; Dorfler, A.; Forster, C.; Zimmermann, K. Brain mechanisms of abnormal temperature perception in cold allodynia induced by ciguatoxin. Ann. Neurol. 2017, 81, 104-116. [CrossRef]

74. Vernoux, J. La ciguatera dans l'île de Saint-Barthélémy: Aspects épidémiologiques, toxicologiques et préventifs. Oceanol. Acta 1988, 11,37-46.

75. Banner, A.H.; Shaw, S.W.; Alender, C.B.; Helfrich, P. Fish Intoxication; Notes on Ciguatera, Its Mode of Action and a Suggested Therapy; Technical Paper; South Pacific Commission: Noumea, New Caledonia, 1963.

76. Ho, A.M.; Fraser, I.M.; Todd, E.C. Ciguatera poisoning: A report of three cases. Ann. Emerg. Med. 1986, 15, 1225-1228. [CrossRef]

77. Lawrence, D.N.; Enriquez, M.B.; Lumish, R.M.; Maceo, A. Ciguatera fish poisoning in Miami. JAMA 1980, 244, 254-258. [CrossRef]

78. Juranovic, L.R.; Park, D.L. Foodborne Toxins of Marine Origin: Ciguatera. In Reviews of Environmental Contamination and Toxicology: Continuation of Residue Reviews; Ware, G.W., Ed.; Reviews of Environmental Contamination and Toxicology; Springer: New York, NY, USA, 1991; pp. 51-94. ISBN 978-1-4612-3054-0.

79. Ting, J.Y.; Brown, A.F. Ciguatera Poisoning: A Global Issue with Common Management Problems. Eur. J. Emerg. Med. 2001, 8, 295-300. [CrossRef]

80. Achaibar, K.C.; Moore, S.; Bain, P.G. Ciguatera poisoning. Pract. Neurol. 2007, 7, 316-322. [CrossRef]

81. Bagnis, R. Concerning a fatal case of ciguatera poisoning in the Tuamotu Islands. Clin. Toxicol. 1970, 3, 579-583. [CrossRef]

82. Defusco, D.J.; O’Dowd, P.; Hokama, Y.; Ott, B.R. Coma due to ciguatera poisoning in Rhode Island. Am. J. Med. 1993, 95, 240-243. [CrossRef]

83. Gatti, C.; Oelher, E.; Legrand, A.M. Severe seafood poisoning in French Polynesia: A retrospective analysis of 129 medical files. Toxicon 2008, 51, 746-753. [CrossRef]

84. Oh, S.-Y.; Kim, D.-H.; Seo, M.-W.; Shin, B.-S. Reversible cerebellar dysfunction associated with ciguatera fish poisoning. J. Emerg. Med. 2012, 43, 674-676. [CrossRef]

85. Chan, T.Y.K. Characteristic Features and Contributory Factors in Fatal Ciguatera Fish Poisoning-Implications for Prevention and Public Education. Am. J. Trop. Med. Hyg. 2016, 94, 704-709. [CrossRef]

86. Vernoux, J.P.; Lahlou, N.; Abbad el Andaloussi, S.; Riyeche, N.; Magras, L.P. A study of the distribution of ciguatoxin in individual Caribbean fish. Acta Trop. 1985, 42, 225-233.

87. Frenette, C.; MacLean, J.D.; Gyorkos, T.W. A large common-source outbreak of ciguatera fish poisoning. J. Infect. Dis. 1988, 158, 1128-1131. [CrossRef]

88. Pearn, J. Chronic Ciguatera: One Organic Cause of the Chronic Fatigue Syndrome. J. Chronic Fatigue Syndr. 1996, 2, 29-34. [CrossRef]

89. Pearn, J. Neurology of ciguatera. J. Neurol. Neurosurg. Psychiatry 2001, 70, 4-8. [CrossRef] [PubMed]

90. Baumann, F.; Bourrat, M.-B.; Pauillac, S. Prevalence, symptoms and chronicity of ciguatera in New Caledonia: Results from an adult population survey conducted in Noumea during 2005. Toxicon 2010, 56, $662-667$. [CrossRef] [PubMed]

91. Vucic, S.; Kiernan, M.C. Normal axonal ion channel function in large peripheral nerve fibers following chronic ciguatera sensitization. Muscle Nerve 2008, 37, 403-405. [CrossRef] [PubMed]

92. Stommel, E.W.; Parsonnet, J.; Jenkyn, L.R. Polymyositis after ciguatera toxin exposure. Arch. Neurol. 1991, 48, 874-877. [CrossRef] [PubMed]

93. Stommel, E.W.; Jenkyn, L.R.; Parsonnet, J. Another case of polymyositis after ciguatera toxin exposure. Arch. Neurol. 1993, 50, 571. [CrossRef]

94. Ohta, R.; Shimabukuro, A.; Kinjo, M. Rheumatoid arthritis following ciguatera poisoning: A case report. J. Rural Med. 2017, 12, 50-52. [CrossRef]

95. Shoemaker, R.C.; House, D.; Ryan, J.C. Defining the neurotoxin derived illness chronic ciguatera using markers of chronic systemic inflammatory disturbances: A case/control study. Neurotoxicol. Teratol. 2010, 32, 633-639. [CrossRef]

96. Ryan, J.C.; Wu, Q.; Shoemaker, R.C. Transcriptomic signatures in whole blood of patients who acquire a chronic inflammatory response syndrome (CIRS) following an exposure to the marine toxin ciguatoxin. BMC Med. Genom. 2015, 8, 15. [CrossRef]

97. Pierre, O.; Misery, L.; Talagas, M.; Le Garrec, R. Immune effects of the neurotoxins ciguatoxins and brevetoxins. Toxicon 2018, 149, 6-19. [CrossRef] 
98. Lipkin, K.M. Ciguatera Poisoning Presenting as Psychiatric Disorder. Arch. Gen. Psychiatry 1989, 46, 384-385. [CrossRef]

99. Arena, P.; Levin, B.; Fleming, L.E.; Friedman, M.A.; Blythe, D. A pilot study of the cognitive and psychological correlates of chronic ciguatera poisoning. Harmful Algae 2004, 3, 51-60. [CrossRef]

100. Friedman, M.A.; Arena, P.; Levin, B.; Fleming, L.; Fernandez, M.; Weisman, R.; Bernstein, J.; Schrank, K.; Blythe, D.; Backer, L.; et al. Neuropsychological study of ciguatera fish poisoning: A longitudinal case-control study. Arch. Clin. Neuropsychol. 2007, 22, 545-553. [CrossRef] [PubMed]

101. Wang, J.; Cao, B.; Yang, X.; Wu, J.; Chan, L.L.; Li, Y. Chronic ciguatoxin poisoning causes emotional and cognitive dysfunctions in rats. Toxicol. Res. 2017, 6, 179-187. [CrossRef] [PubMed]

102. Bidard, J.N.; Vijverberg, H.P.; Frelin, C.; Chungue, E.; Legrand, A.M.; Bagnis, R.; Lazdunski, M. Ciguatoxin is a novel type of $\mathrm{Na}+$ channel toxin. J. Biol. Chem. 1984, 259, 8353-8357.

103. Benoit, E.; Legrand, A.M.; Dubois, J.M. Effects of ciguatoxin on current and voltage clamped frog myelinated nerve fibre. Toxicon 1986, 24, 357-364. [CrossRef]

104. Benoit, E.; Juzans, P.; Legrand, A.M.; Molgo, J. Nodal swelling produced by ciguatoxin-induced selective activation of sodium channels in myelinated nerve fibers. Neuroscience 1996, 71, 1121-1131. [CrossRef]

105. Lewis, R.J.; Endean, R. Direct and indirect effects of ciguatoxin on guinea-pig atria and papillary muscles. Naunyn-Schmiedeberg's Arch. Pharmacol. 1986, 334, 313-322. [CrossRef]

106. Molgo, J.; Comella, J.X.; Legrand, A.M. Ciguatoxin enhances quantal transmitter release from frog motor nerve terminals. Br. J. Pharmacol. 1990, 99, 695-700. [CrossRef]

107. Hamblin, P.A.; McLachlan, E.M.; Lewis, R.J. Sub-nanomolar concentrations of ciguatoxin-1 excite preganglionic terminals in guinea pig sympathetic ganglia. Naunyn-Schmiedeberg's Arch. Pharmacol. 1995, 352, 236-246. [CrossRef]

108. Hogg, R.C.; Lewis, R.J.; Adams, D.J. Ciguatoxin-induced oscillations in membrane potential and action potential firing in rat parasympathetic neurons. Eur. J. Neurosci. 2002, 16, 242-248. [CrossRef]

109. Hogg, R.C.; Lewis, R.J.; Adams, D.J. Ciguatoxin (CTX-1) modulates single tetrodotoxin-sensitive sodium channels in rat parasympathetic neurones. Neurosci. Lett. 1998, 252, 103-106. [CrossRef]

110. Hidalgo, J.; Liberona, J.L.; Molgó, J.; Jaimovich, E. Pacific ciguatoxin- $1 \mathrm{~b}$ effect over $\mathrm{Na}^{+}$and $\mathrm{K}^{+}$currents, inositol 1,4,5-triphosphate content and intracellular $\mathrm{Ca}^{2+}$ signals in cultured rat myotubes. Br. J. Pharmacol. 2002, 137, 1055-1062. [CrossRef] [PubMed]

111. Vetter, I.; Touska, F.; Hess, A.; Hinsbey, R.; Sattler, S.; Lampert, A.; Sergejeva, M.; Sharov, A.; Collins, L.S.; Eberhardt, M.; et al. Ciguatoxins activate specific cold pain pathways to elicit burning pain from cooling. EMBO J. 2012, 31, 3795-3808. [CrossRef]

112. Inserra, M.C.; Israel, M.R.; Caldwell, A.; Castro, J.; Deuis, J.R.; Harrington, A.M.; Keramidas, A.; Garcia-Caraballo, S.; Maddern, J.; Erickson, A.; et al. Multiple sodium channel isoforms mediate the pathological effects of Pacific ciguatoxin-1. Sci. Rep. 2017, 7, 42810. [CrossRef] [PubMed]

113. Birinyi-Strachan, L.C.; Gunning, S.J.; Lewis, R.J.; Nicholson, G.M. Block of voltage-gated potassium channels by Pacific ciguatoxin-1 contributes to increased neuronal excitability in rat sensory neurons. Toxicol. Appl. Pharmacol. 2005, 204, 175-186. [CrossRef]

114. Martin, V.; Vale, C.; Rubiolo, J.A.; Roel, M.; Hirama, M.; Yamashita, S.; Vieytes, M.R.; Botana, L.M. Chronic ciguatoxin treatment induces synaptic scaling through voltage gated sodium channels in cortical neurons. Chem. Res. Toxicol. 2015, 28, 1109-1119. [CrossRef]

115. Mattei, C.; Benoit, E.; Juzans, P.; Legrand, A.M.; Molgó, J. Gambiertoxin (CTX-4B), purified from wild Gambierdiscus toxicus dinoflagellates, induces $\mathrm{Na}(+)$-dependent swelling of single frog myelinated axons and motor nerve terminals in situ. Neurosci. Lett. 1997, 234, 75-78. [CrossRef]

116. Mattei, C.; Molgó, J.; Marquais, M.; Vernoux, J.; Benoit, E. Hyperosmolar D-mannitol reverses the increased membrane excitability and the nodal swelling caused by Caribbean ciguatoxin-1 in single frog myelinated axons. Brain Res. 1999, 847, 50-58. [CrossRef]

117. Mattei, C.; Molgó, J.; Benoit, E. Involvement of both sodium influx and potassium efflux in ciguatoxin-induced nodal swelling of frog myelinated axons. Neuropharmacology 2014, 85, 417-426. [CrossRef]

118. Birinyi-Strachan, L.C.; Davies, M.J.; Lewis, R.J.; Nicholson, G.M. Neuroprotectant effects of iso-osmolar D-mannitol to prevent Pacific ciguatoxin-1 induced alterations in neuronal excitability: A comparison with other osmotic agents and free radical scavengers. Neuropharmacology 2005, 49, 669-686. [CrossRef] 
119. Molgo, J.; Comella, J.X.; Shimahara, T.; Legrand, A.M. Tetrodotoxin-sensitive ciguatoxin effects on quantal release, synaptic vesicle depletion, and calcium mobilization. Ann. N. Y. Acad. Sci. 1991, 635, 485-488. [CrossRef] [PubMed]

120. Mattei, C.; Marquais, M.; Schlumberger, S.; Molgó, J.; Vernoux, J.-P.; Lewis, R.J.; Benoit, E. Analysis of Caribbean ciguatoxin-1 effects on frog myelinated axons and the neuromuscular junction. Toxicon 2010, 56, 759-767. [CrossRef] [PubMed]

121. Sozzi, G.; Marotta, P.; Aldeghi, D.; Tredici, G.; Calvi, L. Polyneuropathy secondary to ciguatoxin poisoning. Ital. J. Neuro. Sci. 1988, 9, 491-495. [CrossRef] [PubMed]

122. Liang, C.-K.; Lo, Y.-K.; Li, J.-Y.; Lai, P.-H. Reversible corpus callosum lesion in ciguatera poisoning. J. Neurol. Neurosurg. Psychiatry 2009, 80,587-588. [CrossRef]

123. Yalachkov, Y.; Hildner, M.; Polomac, N.; Jahnke, K.; Wagner, M.; Baudrexel, S. Cytotoxic edema affecting distinct fiber tracts in ciguatera fish poisoning. Neurology 2019, 92, 145-147. [CrossRef] [PubMed]

124. Terao, K. Ciguatera Toxins: Toxinology. In Seafood and Freshwater Toxins: Pharmacology, Physiology, and Detection; Botana, L.M., Ed.; Food Science and Technology; Marcel Dekker: New York, NY, USA, 2000; pp. 449-472. ISBN 978-0-8247-8956-5.

125. Terao, K.; Ito, E.; Oarada, M.; Ishibashi, Y.; Legrand, A.-M.; Yasumoto, T. Light and electron microscopic studies of pathologic changes induced in mice by ciguatoxin poisoning. Toxicon 1991, 29, 633-643. [CrossRef]

126. Boydron, R.; Laurent, D.; Sauviat, M.P. Un test biologique destiné à identifier les principes actifs des plantes utilisées comme remèdes traditionnels contre l'intoxication ciguatérique en Nouvelle-Calédonie. In Explorer, Exploiter les Toxines et Maîtriser les Organismes Producteurs (Collection Rencontres en Toxinologie); Bon, C., Goudey-Perrière, F., Poulain, B., Puiseux-Dao, S., Eds.; Elsevier: Paris, France, 2001; pp. 63-66. ISBN 978-2-84299-359-7.

127. Sauviat, M.-P.; Boydron-Le Garrec, R.; Masson, J.-B.; Lewis, R.L.; Vernoux, J.-P.; Molgó, J.; Laurent, D.; Benoit, E. Mechanisms involved in the swelling of erythrocytes caused by Pacific and Caribbean ciguatoxins. Blood Cells Mol. Dis. 2006, 36, 1-9. [CrossRef] [PubMed]

128. Terao, K.; Ito, E.; Yasumoto, T. Light and electron microscopic studies of the murine heart after repeated administrations of ciguatoxin or ciguatoxin-4c. Nat. Toxins 1992, 1, 19-26. [CrossRef] [PubMed]

129. Legrand, A.M.; Galonnier, M.; Bagnis, R. Studies on the mode of action of ciguateric toxins. Toxicon 1982, 20, 311-315. [CrossRef]

130. Lewis, R.J.; Endean, R. Mode of action of ciguatoxin from the Spanish Mackerel, Scomberomorus commersoni, on the guinea-pig ileum and vas deferens. J. Pharmacol. Exp. Ther. 1984, 228, 756-760.

131. Tatsumi, M.; Kajiwara, A.; Yasumoto, T.; Ohizumi, Y. Potent excitatory effect of scaritoxin on the guinea-pig vas deferens, taenia caeci and ileum. J. Pharmacol. Exp. Ther. 1985, 235, 783-787. [PubMed]

132. Lewis, R.J.; Wong Hoy, A.W. Comparative action of three major ciguatoxins on guinea-pig atria and ilea. Toxicon 1993, 31, 437-446. [CrossRef]

133. Sauviat, M.-P.; Marquais, M.; Vernoux, J.-P. Muscarinic effects of the Caribbean ciguatoxin C-CTX-1 on frog atrial heart muscle. Toxicon 2002, 40, 1155-1163. [CrossRef]

134. Molgó, J.; Gaudry-Talarmain, Y.M.; Legrand, A.M.; Moulian, N. Ciguatoxin extracted from poisonous moray eels Gymnothorax javanicus triggers acetylcholine release from Torpedo cholinergic synaptosomes via reversed $\mathrm{Na}^{+}-\mathrm{Ca}^{2+}$ exchange. Neurosci. Lett. 1993, 160, 65-68. [CrossRef]

135. Miyahara, J.T.; Oyama, M.M.; Hokama, Y. Mechanism of norepinephrine release by ciguatoxin. In Proceedings of the Fifth International Coral Reef Congress: Symposia and Seminars, Tahiti, France, 27 May-1 June 1985; Gabrie, C., Salvat, B., Eds.; Antenne Museum-EPHE: French Polynesia, France, 1985; Volume 4, pp. 467-474.

136. Lewis, R.J. Negative inotropic and arrhythmic effects of high doses of ciguatoxin on guinea-pig atria and papillary muscles. Toxicon 1988, 26, 639-649. [CrossRef]

137. Lewis, R.J.; Wong Hoy, A.W.; McGiffin, D.C. Action of ciguatoxin on human atrial trabeculae. Toxicon 1992, 30, 907-914. [CrossRef]

138. Ohizumi, Y.; Shibata, S.; Tachibana, K. Mode of the excitatory and inhibitory actions of ciguatoxin in the guinea-pig vas deferens. J. Pharmacol. Exp. Ther. 1981, 217, 475-480.

139. Brock, J.A.; McLachlan, E.M.; Jobling, P.; Lewis, R.J. Electrical activity in rat tail artery during asynchronous activation of postganglionic nerve terminals by ciguatoxin-1. Br. J. Pharmacol. 1995, 116, 2213-2220. [CrossRef] 
140. Brock, J.A.; McLachlan, E.M.; Rayner, S.E. Contribution of alpha-adrenoceptors to depolarization and contraction evoked by continuous asynchronous sympathetic nerve activity in rat tail artery. Br. J. Pharmacol. 1997, 120, 1513-1521. [CrossRef]

141. Mattei, C.; Wen, P.J.; Nguyen-Huu, T.D.; Alvarez, M.; Benoit, E.; Bourdelais, A.J.; Lewis, R.J.; Baden, D.G.; Molgó, J.; Meunier, F.A. Brevenal inhibits pacific ciguatoxin-1B-induced neurosecretion from bovine chromaffin cells. PLoS ONE 2008, 3, e3448. [CrossRef]

142. Nguyen-Huu, T.D.; Mattei, C.; Wen, P.J.; Bourdelais, A.J.; Lewis, R.J.; Benoit, E.; Baden, D.G.; Molgó, J.; Meunier, F.A. Ciguatoxin-induced catecholamine secretion in bovine chromaffin cells: Mechanism of action and reversible inhibition by brevenal. Toxicon 2010, 56, 792-796. [CrossRef] [PubMed]

143. Martin, V.; Vale, C.; Hirama, M.; Yamashita, S.; Rubiolo, J.A.; Vieytes, M.R.; Botana, L.M. Synthetic ciguatoxin CTX 3C induces a rapid imbalance in neuronal excitability. Chem. Res. Toxicol. 2015, 28, 1095-1108. [CrossRef] [PubMed]

144. Touska, F.; Sattler, S.; Malsch, P.; Lewis, R.J.; Reeh, P.W.; Zimmermann, K. Ciguatoxins Evoke Potent CGRP Release by Activation of Voltage-Gated Sodium Channel Subtypes NaV1.9, NaV1.7 and NaV1.1. Mar. Drugs 2017, 15, 269. [CrossRef] [PubMed]

145. Le Garrec, R.; L'herondelle, K.; Le Gall-Ianotto, C.; Lebonvallet, N.; Leschiera, R.; Buhe, V.; Talagas, M.; Vetter, I.; Lewis, R.J.; Misery, L. Release of neuropeptides from a neuro-cutaneous co-culture model: A novel in vitro model for studying sensory effects of ciguatoxins. Toxicon 2016, 116, 4-10. [CrossRef]

146. L'Herondelle, K.; Pierre, O.; Fouyet, S.; Leschiera, R.; Le Gall-Ianotto, C.; Philippe, R.; Buscaglia, P.; Mignen, O.; Talagas, M.; Lewis, R.J.; et al. PAR2, keratinocytes and cathepsin S mediate the sensory effects of ciguatoxins responsible for ciguatera poisoning. J. Investig. Dermatol. 2020. [CrossRef]

147. Gaudry-Talarmain, Y.M.; Molgo, J.; Meunier, F.A.; Moulian, N.; Legrand, A.M. Reversed mode Na(+)-Ca2+ exchange activated by ciguatoxin (CTX-1b) enhances acetylcholine release from Torpedo cholinergic synaptosomes. Ann. N. Y. Acad. Sci. 1996, 779, 404-406. [CrossRef]

148. Molgó, J.; Shimahara, T.; Legrand, A.M. Ciguatoxin, extracted from poisonous morays eels, causes sodium-dependent calcium mobilization in NG108-15 neuroblastoma $\times$ glioma hybrid cells. Neurosci. Lett. 1993, 158, 147-150. [CrossRef]

149. Kumar-Roiné, S.; Matsui, M.; Chinain, M.; Laurent, D.; Pauillac, S. Modulation of inducible nitric oxide synthase gene expression in RAW 264.7 murine macrophages by Pacific ciguatoxin. Nitric Oxide 2008, 19, 21-28. [CrossRef]

150. Matsui, M.; Kumar-Roine, S.; Darius, H.T.; Chinain, M.; Laurent, D.; Pauillac, S. Pacific ciguatoxin 1B-induced modulation of inflammatory mediators in a murine macrophage cell line. Toxicon 2010, 56, 776-784. [CrossRef]

151. Rubiolo, J.A.; Vale, C.; Boente-Juncal, A.; Hirama, M.; Yamashita, S.; Camina, M.; Vieytes, M.R.; Botana, L.M. Transcriptomic Analysis of Ciguatoxin-Induced Changes in Gene Expression in Primary Cultures of Mice Cortical Neurons. Toxins 2018, 10, 192. [CrossRef]

152. Ryan, J.C.; Bottein Dechraoui, M.-Y.; Morey, J.S.; Rezvani, A.; Levin, E.D.; Gordon, C.J.; Ramsdell, J.S.; Van Dolah, F.M. Transcriptional profiling of whole blood and serum protein analysis of mice exposed to the neurotoxin Pacific Ciguatoxin-1. Neurotoxicology 2007, 28, 1099-1109. [CrossRef] [PubMed]

153. Ryan, J.C.; Morey, J.S.; Bottein, M.-Y.D.; Ramsdell, J.S.; Van Dolah, F.M. Gene expression profiling in brain of mice exposed to the marine neurotoxin ciguatoxin reveals an acute anti-inflammatory, neuroprotective response. BMC Neurosci. 2010, 11, 107. [CrossRef] [PubMed]

154. Morey, J.S.; Ryan, J.C.; Bottein Dechraoui, M.-Y.; Rezvani, A.H.; Levin, E.D.; Gordon, C.J.; Ramsdell, J.S.; Van Dolah, F.M. Liver genomic responses to ciguatoxin: Evidence for activation of phase I and phase II detoxification pathways following an acute hypothermic response in mice. Toxicol. Sci. 2008, 103, 298-310. [CrossRef] [PubMed]

155. Li, K.-M. Ciguatera Fish Poison: A Cholinesterase Inhibitor. Science 1965, 147, 1580-1581. [CrossRef] [PubMed]

156. Kew, C.K.; Ming, L.K.; Hang, Q.M.Y. The mechanism of respiratory failure in ciguatera poisoning. J. Pathol. 1969, 97, 89-92. [CrossRef]

157. Setliff, J.A.; Rayner, M.D.; Ki Hong, S. Effect of Ciguatoxin on sodium transport across the frog skin. Toxicol. Appl. Pharm. 1971, 18, 676-684. [CrossRef] 
158. Lombet, A.; Bidard, J.-N.; Lazdunski, M. Ciguatoxin and brevetoxins share a common receptor site on the neuronal voltage-dependent $\mathrm{Na}+$ channel. FEBS Lett. 1987, 219, 355-359. [CrossRef]

159. Dechraoui, M.-Y.; Naar, J.; Pauillac, S.; Legrand, A.-M. Ciguatoxins and brevetoxins, neurotoxic polyether compounds active on sodium channels. Toxicon 1999, 37, 125-143. [CrossRef]

160. Cestèle, S.; Catterall, W.A. Molecular mechanisms of neurotoxin action on voltage-gated sodium channels. Biochimie 2000, 82, 883-892. [CrossRef]

161. Seino, A.; Kobayashi, M.; Momose, K.; Yasumoto, T.; Ohizumi, Y. The mode of inotropic action of ciguatoxin on guinea-pig cardiac muscle. Br. J. Pharmacol. 1988, 95, 876-882. [CrossRef]

162. Strachan, L.C.; Lewis, R.J.; Nicholson, G.M. Differential actions of pacific ciguatoxin-1 on sodium channel subtypes in mammalian sensory neurons. J. Pharmacol. Exp. Ther. 1999, 288, 379-388. [PubMed]

163. Cummins, T.R.; Sheets, P.L.; Waxman, S.G. The roles of sodium channels in nociception: Implications for mechanisms of pain. Pain 2007, 131, 243-257. [CrossRef] [PubMed]

164. Patel, R.; Brice, N.L.; Lewis, R.J.; Dickenson, A.H. Ionic mechanisms of spinal neuronal cold hypersensitivity in ciguatera. Eur. J. Neurosci. 2015, 42, 3004-3011. [CrossRef] [PubMed]

165. Dib-Hajj, S.D.; Cummins, T.R.; Black, J.A.; Waxman, S.G. Sodium channels in normal and pathological pain. Annu. Rev. Neurosci. 2010, 33, 325-347. [CrossRef]

166. Zimmermann, K.; Leffler, A.; Babes, A.; Cendan, C.M.; Carr, R.W.; Kobayashi, J.; Nau, C.; Wood, J.N.; Reeh, P.W. Sensory neuron sodium channel Nav1.8 is essential for pain at low temperatures. Nature 2007, 447, 855-858. [CrossRef]

167. Lee, J.-H.; Park, C.-K.; Chen, G.; Han, Q.; Xie, R.-G.; Liu, T.; Ji, R.-R.; Lee, S.-Y. A monoclonal antibody that targets a NaV1.7 channel voltage sensor for pain and itch relief. Cell 2014, 157, 1393-1404. [CrossRef]

168. Devigili, G.; Eleopra, R.; Pierro, T.; Lombardi, R.; Rinaldo, S.; Lettieri, C.; Faber, C.G.; Merkies, I.S.J.; Waxman, S.G.; Lauria, G. Paroxysmal itch caused by gain-of-function Nav1.7 mutation. Pain 2014, 155, 1702-1707. [CrossRef]

169. Salvatierra, J.; Diaz-Bustamante, M.; Meixiong, J.; Tierney, E.; Dong, X.; Bosmans, F. A disease mutation reveals a role for NaV1.9 in acute itch. J. Clin. Investig. 2018. [CrossRef]

170. Shields, S.D.; Deng, L.; Reese, R.M.; Dourado, M.; Tao, J.; Foreman, O.; Chang, J.H.; Hackos, D.H. Insensitivity to Pain upon Adult-Onset Deletion of Nav1.7 or Its Blockade with Selective Inhibitors. J. Neurosci. 2018, 38, 10180-10201. [CrossRef]

171. Kühn, H.; Kappes, L.; Wolf, K.; Gebhardt, L.; Neurath, M.F.; Reeh, P.; Fischer, M.J.M.; Kremer, A.E. Complementary roles of murine NaV1.7, NaV1.8 and NaV1.9 in acute itch signalling. Sci. Rep. 2020, 10, 2326. [CrossRef]

172. Minett, M.S.; Nassar, M.A.; Clark, A.K.; Passmore, G.; Dickenson, A.H.; Wang, F.; Malcangio, M.; Wood, J.N. Distinct Nav1.7-dependent pain sensations require different sets of sensory and sympathetic neurons. Nat. Commun. 2012, 3, 791. [CrossRef] [PubMed]

173. Dib-Hajj, S.D.; Black, J.A.; Waxman, S.G. NaV1.9: A sodium channel linked to human pain. Nat. Rev. Neurosci. 2015, 16, 511-519. [CrossRef] [PubMed]

174. Amaya, F.; Decosterd, I.; Samad, T.A.; Plumpton, C.; Tate, S.; Mannion, R.J.; Costigan, M.; Woolf, C.J. Diversity of expression of the sensory neuron-specific TTX-resistant voltage-gated sodium ion channels SNS and SNS2. Mol. Cell. Neurosci. 2000, 15, 331-342. [CrossRef] [PubMed]

175. Schlumberger, S.; Mattei, C.; Molgó, J.; Benoit, E. Dual action of a dinoflagellate-derived precursor of Pacific ciguatoxins (P-CTX-4B) on voltage-dependent $\mathrm{K}+$ and $\mathrm{Na}+$ channels of single myelinated axons. Toxicon 2010, 56, 768-775. [CrossRef]

176. Ghiaroni, V.; Sasaki, M.; Fuwa, H.; Rossini, G.P.; Scalera, G.; Yasumoto, T.; Pietra, P.; Bigiani, A. Inhibition of voltage-gated potassium currents by gambierol in mouse taste cells. Toxicol. Sci. 2005, 85, 657-665. [CrossRef]

177. Cuypers, E.; Abdel-Mottaleb, Y.; Kopljar, I.; Rainier, J.D.; Raes, A.L.; Snyders, D.J.; Tytgat, J. Gambierol, a toxin produced by the dinoflagellate Gambierdiscus toxicus, is a potent blocker of voltage-gated potassium channels. Toxicon 2008, 51, 974-983. [CrossRef]

178. Ghiaroni, V.; Fuwa, H.; Inoue, M.; Sasaki, M.; Miyazaki, K.; Hirama, M.; Yasumoto, T.; Rossini, G.P.; Scalera, G.; Bigiani, A. Effect of ciguatoxin $3 \mathrm{C}$ on voltage-gated $\mathrm{Na}+$ and $\mathrm{K}+$ currents in mouse taste cells. Chem. Senses 2006, 31, 673-680. [CrossRef] 
179. Benoit, E.; Mattei, C.; Brown, S.; Molgó, J. Confocal microscopy and passive staining with the styryl dye FM1-43: A convenient method to evaluate morphometric changes in nodes of Ranvier of single living myelinated axons. In Microscopy and Imaging Science Practical Approaches to Applied Research and Education; Méndez-Vilas, A., Ed.; Microscopy Book Series; Formatex Research Center: Badajoz, Espagne, 2017; pp. 73-80. ISBN 978-84-942134-9-6.

180. Hoffman, P.A.; Granade, H.R.; McMillan, J.P. The mouse ciguatoxin bioassay: A dose-response curve and symptomatology analysis. Toxicon 1983, 21, 363-369. [CrossRef]

181. Lewis, R.J. Detection of Ciguatoxins and related Benthic Dinoflagellate Toxins: In vivo and in vitro Methods. In Manual on Harmful Marine Microalgae; IOC Manuals and Guides No. 33; Hallegraeff, G., Anderson, D., Cembella, A., Eds.; UNESCO: Paris, France, 1995; pp. 135-161.

182. Geller, R.J.; Benowitz, N.L. Orthostatic hypotension in ciguatera fish poisoning. Arch. Intern. Med. 1992, 152, 2131-2133. [CrossRef]

183. Armstrong, P.; Murray, P.; Nesdale, A.; Peckler, B. Ciguatera fish poisoning. NZMJ 2016, 129, $113-117$.

184. Coombe, I.F.; Capra, M.F.; Flowers, A.E.; Cameron, J. Pathological changes in the mammalian gut following administration of ciguatoxin. In Progress in Venom and Toxin Research, Proceedings of the First Asia-Pacific Congress on Animal, Plant and Microbial Toxins, Singapore, 24-27 June 1987; Gopalakrishnakone, P., Tan, C.K., Eds.; Faculty of Medicine, National University of Singapore: Singapore, 1987; pp. 405-410. ISBN 978-9971-62-152-0.

185. Ito, E.; Yasumoto, T.; Terao, K. Morphological observations of diarrhea in mice caused by experimental ciguatoxicosis. Toxicon 1996, 34, 111-122.

186. Glatte, P.; Buchmann, S.J.; Hijazi, M.M.; Illigens, B.M.-W.; Siepmann, T. Architecture of the Cutaneous Autonomic Nervous System. Front. Neurol. 2019, 10, 970. [CrossRef] [PubMed]

187. Ohizumi, Y.; Ishida, Y.; Shibata, S. Mode of the ciguatoxin-induced supersensitivity in the guinea-pig vas deferens. J. Pharmacol. Exp. Ther. 1982, 221, 748-752. [PubMed]

188. Zegarska, B.; Lelińska, A.; Tyrakowski, T. Clinical and experimental aspects of cutaneous neurogenic inflammation. Pharmacol. Rep. 2006, 58, 13-21.

189. McCoy, E.S.; Taylor-Blake, B.; Street, S.E.; Pribisko, A.L.; Zheng, J.; Zylka, M.J. Peptidergic CGRP $\alpha$ primary sensory neurons encode heat and itch and tonically suppress sensitivity to cold. Neuron 2013, 78, 138-151. [CrossRef]

190. Rogoz, K.; Andersen, H.H.; Lagerström, M.C.; Kullander, K. Multimodal use of calcitonin gene-related peptide and substance $\mathrm{P}$ in itch and acute pain uncovered by the elimination of vesicular glutamate transporter 2 from transient receptor potential cation channel subfamily V member 1 neurons. J. Neurosci. 2014, 34, 14055-14068. [CrossRef] [PubMed]

191. Stinn, J.F.; De Sylva, D.P.; Fleming, L.E.; Hack, E. Geographical information systems and ciguatera fish poisoning in the tropical Western Atlantic region. In Proceedings of the 1998 Geographic Information Systems in Public Health Conference, Third National Conference, San Diego, CA, USA, 18-20 August 2000; pp. 223-233.

192. Steinhoff, M.; Vergnolle, N.; Young, S.H.; Tognetto, M.; Amadesi, S.; Ennes, H.S.; Trevisani, M.; Hollenberg, M.D.; Wallace, J.L.; Caughey, G.H.; et al. Agonists of proteinase-activated receptor 2 induce inflammation by a neurogenic mechanism. Nat. Med. 2000, 6, 151-158. [CrossRef]

193. Vergnolle, N.; Bunnett, N.W.; Sharkey, K.A.; Brussee, V.; Compton, S.J.; Grady, E.F.; Cirino, G.; Gerard, N.; Basbaum, A.I.; Andrade-Gordon, P.; et al. Proteinase-activated receptor-2 and hyperalgesia: A novel pain pathway. Nat. Med. 2001, 7, 821-826. [CrossRef] [PubMed]

194. Steinhoff, M.; Neisius, U.; Ikoma, A.; Fartasch, M.; Heyer, G.; Skov, P.S.; Luger, T.A.; Schmelz, M. Proteinase-activated receptor-2 mediates itch: A novel pathway for pruritus in human skin. J. Neurosci. 2003, 23, 6176-6180.

195. Zhao, P.; Barr, T.P.; Hou, Q.; Dib-Hajj, S.D.; Black, J.A.; Albrecht, P.J.; Petersen, K.; Eisenberg, E.; Wymer, J.P.; Rice, F.L.; et al. Voltage-gated sodium channel expression in rat and human epidermal keratinocytes: Evidence for a role in pain. Pain 2008, 139, 90-105. [CrossRef]

196. Wilson, S.R.; Thé, L.; Batia, L.M.; Beattie, K.; Katibah, G.E.; McClain, S.P.; Pellegrino, M.; Estandian, D.M.; Bautista, D.M. The epithelial cell-derived atopic dermatitis cytokine TSLP activates neurons to induce itch. Cell 2013, 155, 285-295. [CrossRef] [PubMed] 
197. Pang, Z.; Sakamoto, T.; Tiwari, V.; Kim, Y.-S.; Yang, F.; Dong, X.; Güler, A.D.; Guan, Y.; Caterina, M.J. Selective keratinocyte stimulation is sufficient to evoke nociception in mice. Pain 2015, 156, 656-665. [CrossRef] [PubMed]

198. Baumbauer, K.M.; DeBerry, J.J.; Adelman, P.C.; Miller, R.H.; Hachisuka, J.; Lee, K.H.; Ross, S.E.; Koerber, H.R.; Davis, B.M.; Albers, K.M. Keratinocytes can modulate and directly initiate nociceptive responses. Elife Sci. 2015, 4, e09674. [CrossRef]

199. Moehring, F.; Cowie, A.M.; Menzel, A.D.; Weyer, A.D.; Grzybowski, M.; Arzua, T.; Geurts, A.M.; Palygin, O.; Stucky, C.L. Keratinocytes mediate innocuous and noxious touch via ATP-P2 $\times 4$ signaling. Elife 2018, 7, e31684. [CrossRef] [PubMed]

200. Talagas, M.; Lebonvallet, N.; Leschiera, R.; Marcorelles, P.; Misery, L. What about physical contacts between epidermal keratinocytes and sensory neurons? Exp. Dermatol. 2018, 27, 9-13. [CrossRef] [PubMed]

201. Kumar, G.; Au, N.P.B.; Lei, E.N.Y.; Mak, Y.L.; Chan, L.L.H.; Lam, M.H.W.; Chan, L.L.; Lam, P.K.S.; Ma, C.H.E. Acute Exposure to Pacific Ciguatoxin Reduces Electroencephalogram Activity and Disrupts Neurotransmitter Metabolic Pathways in Motor Cortex. Mol. Neurobiol. 2017, 54, 5590-5603. [CrossRef]

202. Patapoutian, A.; Tate, S.; Woolf, C.J. Transient receptor potential channels: Targeting pain at the source. Nat. Rev. Drug Discov. 2009, 8, 55-68. [CrossRef]

203. Martin-Yken, H.; Gironde, C.; Derick, S.; Darius, H.T.; Furger, C.; Laurent, D.; Chinain, M. Ciguatoxins activate the Calcineurin signalling pathway in yeasts: Potential for development of an alternative detection tool? Environ. Res. 2018, 162, 144-151. [CrossRef]

204. Oehler, E.; Gatti, C.; Legrand, A.M.; Ghawche, F. Ciguatera and acute polyradiculoneuritis. Description of two cases in French Polynesia: Immunoallergic hypothesis? Med. Trop. 2009, 69, 75-77.

205. Cameron, J.; Flowers, A.E.; Capra, M.F. Effects of ciguatoxin on nerve excitability in rats (Part I). J. Neurol. Sci. 1991, 101, 87-92.

206. Cameron, J.; Flowers, A.E.; Capra, M.F. Electrophysiological studies on ciguatera poisoning in man (Part II). J. Neurol. Sci. 1991, 101, 93-97. [PubMed]

207. Butera, R.; Prockop, L.D.; Buonocore, M.; Locatelli, C.; Gandini, C.; Manzo, L. Mild ciguatera poisoning: Case reports with neurophysiological evaluations. Muscle Nerve 2000, 23, 1598-1603. [PubMed]

208. Jimenez-Andrade, J.M.; Herrera, M.B.; Ghilardi, J.R.; Vardanyan, M.; Melemedjian, O.K.; Mantyh, P.W. Vascularization of the dorsal root ganglia and peripheral nerve of the mouse: Implications for chemical-induced peripheral sensory neuropathies. Mol. Pain 2008, 4, 10. [CrossRef] [PubMed]

209. Au, N.P.B.; Kumar, G.; Asthana, P.; Tin, C.; Mak, Y.L.; Chan, L.L.; Lam, P.K.S.; Ma, C.H.E. Ciguatoxin reduces regenerative capacity of axotomized peripheral neurons and delays functional recovery in pre-exposed mice after peripheral nerve injury. Sci. Rep. 2016, 6, 26809. [CrossRef]

210. Zhang, X.; Cao, B.; Wang, J.; Liu, J.; Tung, V.O.V.; Lam, P.K.S.; Chan, L.L.; Li, Y. Neurotoxicity and Reactive Astrogliosis in the Anterior Cingulate Cortex in Acute Ciguatera Poisoning. Neuromol. Med. 2013, 15, 310-323. [CrossRef]

211. Asthana, P.; Zhang, N.; Kumar, G.; Chine, V.B.; Singh, K.K.; Mak, Y.L.; Chan, L.L.; Lam, P.K.S.; Ma, C.H.E. Pacific Ciguatoxin Induces Excitotoxicity and Neurodegeneration in the Motor Cortex Via Caspase 3 Activation: Implication for Irreversible Motor Deficit. Mol. Neurobiol. 2018, 55, 6769-6787. [CrossRef]

212. Bourdy, G.; Cabalion, P.; Amade, P.; Laurent, D. Traditional remedies used in the Western Pacific for the treatment of ciguatera poisoning. J. Ethnopharmacol. 1992, 36, 163-174. [CrossRef]

213. Kumar-Roiné, S.; Darius, H.T.; Matsui, M.; Fabre, N.; Haddad, M.; Chinain, M.; Pauillac, S.; Laurent, D. A review of traditional remedies of ciguatera fish poisoning in the Pacific. Phytother. Res. 2011, 25, 947-958. [CrossRef] [PubMed]

214. Amade, P.; Laurent, D. Screening of Traditional Remedies Used in Ciguatera Fish Poisoning Treatment. In Recent Advances in Toxinology Research; Gopalakrishnakone, P., Tan, C.K., Eds.; Venom \& Toxin Research Group, National University of Singapore: Singapore, 1992; pp. 503-508. ISBN 978-9971-62-283-1.

215. Laurent, D.; Amade, P. Remèdes Traditionnels Contre la Ciguatera en Nouvelle Calédonie; ORSTOM: Nouméa, New Caledonia, 1992; p. 84.

216. Benoit, E.; Laurent, D.; Mattei, C.; Legrand, A.-M.; Molgo, J. Reversal of Pacific ciguatoxin-1B effects on myelinated axons by agents used in ciguatera treatment. Cybium 2000, 24, 33-40. 
217. Boydron-Le Garrec, R.; Benoit, E.; Sauviat, M.-P.; Lewis, R.J.; Molgó, J.; Laurent, D. Ability of some plant extracts, traditionally used to treat ciguatera fish poisoning, to prevent the in vitro neurotoxicity produced by sodium channel activators. Toxicon 2005, 46, 625-634. [CrossRef]

218. Kumar Roiné, S.; Matsui, M.; Reybier, K.; Darius, H.T.; Chinain, M.; Pauillac, S.; Laurent, D. Ability of certain plant extracts traditionally used to treat ciguatera fish poisoning to inhibit nitric oxide production in RAW 264.7 macrophages. J. Ethnopharmacol. 2009, 123, 369-377. [CrossRef] [PubMed]

219. Matsui, M.; Kumar-Roine, S.; Taina Darius, H.; Chinain, M.; Laurent, D.; Pauillac, S. Characterisation of the anti-inflammatory potential of Vitex trifolia L. (Labiatae), a multipurpose plant of the Pacific traditionnal medicine. J. Ethnopharmacol. 2009, 126, 427-433. [CrossRef] [PubMed]

220. Tadahide, N.; Ryuta, T.; Yoropiy, A. Ciguatera fish poisoning in Ulithi Atoll, Yap State, Micronesia. In Occasional Papers No. 39; Kagoshima University Research Center for the Pacific Islands: Kagoshima, Japan, 2003; pp. 83-86.

221. Rossi, F.; Jullian, V.; Pawlowiez, R.; Kumar-Roine, S.; Haddad, M.; Darius, H.T.; Gaertner-Mazouni, N.; Chinain, M.; Laurent, D. Protective effect of Heliotropium foertherianum (Boraginaceae) folk remedy and its active compound, rosmarinic acid, against a Pacific ciguatoxin. J. Ethnopharmacol. 2012, 143, $33-40$. [CrossRef] [PubMed]

222. Braidy, N.; Matin, A.; Rossi, F.; Chinain, M.; Laurent, D.; Guillemin, G.J. Neuroprotective Effects of Rosmarinic Acid on Ciguatoxin in Primary Human Neurons. Neurotox. Res. 2014, 25, 226-234. [CrossRef] [PubMed]

223. Davis, R.T.; Villar, L.A. Symptomatic improvement with amitriptyline in ciguatera fish poisoning. N. Engl. J. Med. 1986, 315, 65.

224. Calvert, G.M.; Hryhorczuk, D.O.; Leikin, J.B. Treatment of ciguatera fish poisoning with amitriptyline and nifedipine. J. Toxicol. Clin. Toxicol. 1987, 25, 423-428.

225. Lange, W.R.; Kreider, S.D.; Hattwick, M.; Hobbs, J. Potential benefit of tocainide in the treatment of ciguatera: Report of three cases. Am. J. Med. 1988, 84, 1087-1088. [CrossRef]

226. Crump, J.A.; McLay, C.L.; Chambers, S.T. Ciguatera fish poisoning. Postgrad. Med. J. 1999, 75, 678-679. [CrossRef]

227. Derouiche, F.; Cohen, E.; Rodier, G.; Boulay, C.; Courtois, S. Ciguatera and peripheral neuropathy: A case report. Rev. Neurol. 2000, 156, 514-516.

228. Legrand, A.-M.; Lotte, C.; Bagnis, R. Respiratory and cardio-vascular effects of ciguatoxin in cats; antagonistic action of Hexamethonium, Atropine, Propranolol, Phentolamine, Yohimbine, Prazosin, Verapamil, Calcium and Lidocaine. In Proceedings of the Fifth International Coral Reef Conference, Tahiti, France, 27 May-1 June 1985; Gabrie, C., Salvat, B., Eds.; Antenne Museum-EPHE: Moorea, French Polynesia, 1985; pp. 463-466.

229. Cameron, J.; Flowers, A.E.; Capra, M.F. Modification of the peripheral nerve disturbance in ciguatera poisoning in rats with lidocaine. Muscle Nerve 1993, 16, 782-786. [CrossRef]

230. Perez, C.M.; Vasquez, P.A.; Perret, C.F. Treatment of ciguatera poisoning with gabapentin. N. Engl. J. Med. 2001, 344, 692-693. [CrossRef] [PubMed]

231. Brett, J.; Murnion, B. Pregabalin to treat ciguatera fish poisoning. Clin Toxicol. 2015, 53, 588. [CrossRef] [PubMed]

232. Bourdelais, A.J.; Campbell, S.; Jacocks, H.; Naar, J.; Wright, J.L.C.; Carsi, J.; Baden, D.G. Brevenal Is a Natural Inhibitor of Brevetoxin Action in Sodium Channel Receptor Binding Assays. Cell. Mol. Neurobiol. 2004, 24, 553-563. [CrossRef]

233. Gold, E.P.; Jacocks, H.M.; Bourdelais, A.J.; Baden, D.G. Brevenal, a brevetoxin antagonist from Karenia brevis, binds to a previously unreported site on mammalian sodium channels. Harmful Algae 2013, 26, 12-19. [CrossRef] [PubMed]

234. Inoue, M.; Lee, N.; Tsumuraya, T.; Fujii, I.; Hirama, M. Use of monoclonal antibodies as an effective strategy for treatment of ciguatera poisoning. Toxicon 2009, 53, 802-805. [CrossRef]

235. Palafox, N.A.; Jain, L.G.; Pinano, A.Z.; Gulick, T.M.; Williams, R.K.; Schatz, I.J. Successful treatment of ciguatera fish poisoning with intravenous mannitol. JAMA 1988, 259, 2740-2742.

236. Blythe, D.G.; De Sylva, D.P.; Fleming, L.E.; Ayyar, R.A.; Baden, D.G.; Shrank, K. Clinical experience with i.v. Mannitol in the treatment of ciguatera. Bull. Soc. Pathol. Exot. 1992, 85, 425-426.

237. Mullins, M.E.; Hoffman, R.S. Is mannitol the treatment of choice for patients with ciguatera fish poisoning? Clin. Toxicol. 2017, 55, 947-955. [CrossRef] 
238. Schnorf, H.; Taurarii, M.; Cundy, T. Ciguatera fish poisoning: A double-blind randomized trial of mannitol therapy. Neurology 2002, 58, 873-880. [CrossRef]

239. Adams, M.J. An outbreak of ciguatera poisoning in a group of scuba divers. J. Wilderness Med. 1993, 4, 304-311. [CrossRef]

Publisher's Note: MDPI stays neutral with regard to jurisdictional claims in published maps and institutional affiliations.

(C) 2020 by the authors. Licensee MDPI, Basel, Switzerland. This article is an open access article distributed under the terms and conditions of the Creative Commons Attribution (CC BY) license (http://creativecommons.org/licenses/by/4.0/). 